Article

\title{
Side-by-Side Comparison of Clean and Biomass-Derived, Impurity-Containing Syngas as Substrate for Acetogenic Fermentation with Clostridium ljungdahlii
}

\author{
Alba Infantes ${ }^{1, *}$, Michaela Kugel ${ }^{1}$, Klaus Raffelt ${ }^{2}$ and Anke Neumann ${ }^{1, *(D)}$ \\ 1 Technical Biology, Institute of Process Engineering in Life Science 2, Karlsruhe Institute of Technology (KIT), \\ 76131 Karlsruhe, Germany; michaela.kugel@kit.edu \\ 2 Institute of Catalysis Research and Technology (IKFT), Karlsruhe Institute of Technology (KIT), \\ 76344 Eggenstein-Leopoldshafen, Germany; klaus.raffelt@kit.edu \\ * Correspondence: alba.infantes@kit.edu (A.I.); anke.neumann@kit.edu (A.N.)
}

Received: 26 June 2020; Accepted: 15 August 2020; Published: 19 August 2020

\begin{abstract}
Syngas, the product of biomass gasification, can play an important role in moving towards the production of renewable chemical commodities, by using acetogenic bacteria to ferment those gaseous mixtures. Due to the complex and changing nature of biomass, the composition and the impurities present in the final biomass-derived syngas will vary. Because of this, it is important to assess the impact of these factors on the fermentation outcome, in terms of yields, productivity, and product formation and ratio. In this study, Clostridium ljungdahlii was used in a fed-batch fermentation system to analyze the effect of three different biomass-derived syngases, and to compare them to equivalent, clean syngas mixtures. Additionally, four other clean syngas mixtures were used, and the effects on product ratio, productivity, yield, and growth were documented. All biomass-derived syngases were suitable to be used as substrates, without experiencing any complete inhibitory effects. From the obtained results, it is clear that the type of syngas, biomass-derived or clean, had the greatest impact on product formation ratios, with all biomass-derived syngases producing more ethanol, albeit with lesser total productivity.
\end{abstract}

Keywords: syngas fermentation; acetogen; Clostridium ljungdahlii; biomass-derived syngas; syngas impurities; acetate; ethanol

\section{Introduction}

Nowadays, there is a growing interest and increased research efforts towards finding more environmentally friendly and renewable energy sources. Fossil fuels are still the main source of energy, and the source of a great proportion of widely use industrial commodities [1]. This, combined with the population growth, is causing a rise in the release of $\mathrm{CO}_{2}$ into the atmosphere [2]. At the same time, reducing the $\mathrm{CO}_{2}$ emissions has been identified as a much needed measure to prevent the global temperature increase [3].

Biomass is seen as an important source for renewable commodity chemicals and some liquid hydrocarbon fuels: it can be gasified, including lignocellulosic biomass, waste and non-food crops, to produce syngas, which is composed mainly by $\mathrm{CO}, \mathrm{CO}_{2}$, and $\mathrm{H}_{2}$ [4]. This gasification technology is well-established and has been broadly studied [5]. Carboxydotrophic, acetogenic microorganisms possess the ability to ferment such a gaseous mixture, using it as energy and carbon source via the reductive acetyl-coenzyme A pathway (or Wood-Ljundahl pathway, WLP) [6]. The fermentation products are mainly acetate, but ethanol and other longer-chain products, such as butyrate, butanol, 
hexanoate, or hexanol can also be produced by selected strains [7]. Acetogenic fermentation of syngas has been lately gaining ever more attention, since commercial syngas or waste gas fermentation plants are being developed, or are already operational [8,9]. By implementing syngas fermentation, using carboxydotrophic bacteria as biocatalysts, to obtain the aforementioned commodities, the food or fuel dilemma can be overcome.

Moreover, an additional advantage includes the robustness against impurities and varying $\mathrm{CO}: \mathrm{CO}_{2}: \mathrm{H}_{2}$ ratios compared to the more delicate traditional catalysts [10-12]. This gives the acetogenic fermentation of syngas an advantage since different biomass sources and gasification techniques will inevitably produce different gas compositions and impurities $[13,14]$. An important point that needs to be considered, and addressed, for the success of the syngas fermentation technology is the effect of the different gas compositions. In the aqueous fermentation broth, $\mathrm{CO}_{2}$ is 48 times more soluble than $\mathrm{CO}$ (at $273.15 \mathrm{~K}$ and $101.33 \mathrm{kPa}$ ), and 80 times more soluble than $\mathrm{H}_{2}$ (at $273.15 \mathrm{~K}$ and $101.33 \mathrm{kPa}$ ) [15]. $\mathrm{CO}$ and $\mathrm{H}_{2}$ are the electron and reducing equivalent supply, and are needed for producing more reduced compounds, such as ethanol, rather than acetate. The partial pressures of the gases will, hence, influence the product distribution, as well as the yield [16].

Clostridium ljungdahlii, the model acetogen used in this study, produces acetate as the main fermentation product, but is also able to generate ethanol. The stoichiometry of the WLP reactions implies that, when using $\mathrm{CO}$ alone, $50 \%$ of the carbon could be fixed into acetate, producing $0.5 \mathrm{~mol}$ of $\mathrm{CO}_{2}$ per mol of $\mathrm{CO}$ used. Considering ethanol as the only end product, only $33 \%$ of the carbon would be fixed, releasing the remaining amount as $\mathrm{CO}_{2}$. If $\mathrm{H}_{2}$ is present at an equimolar ratio to $\mathrm{CO}$, then theoretically all carbon would be fixed to acetate, or $67 \%$ of the carbon would be converted to ethanol. For a mixture of $\mathrm{CO}_{2}$ and $\mathrm{H}_{2}$, complete fixation into acetate would require a 1:2 molar ratio; for ethanol, it would need to be 1:3 [17-19]. These stoichiometric ratios do not apply for the growing phase though, since the carbon and reducing equivalents needed for biomass increase are not contemplated. Only with resting cells can these ratios be balanced, and only in the case of homoacetogenesis. This represents a challenge of its own, since the result of a more realistic scenario of mixed products and varying gas composition cannot be directly inferred.

In addition, the biomass-derived syngas can contain several impurities, such as volatile tars, ethane $\left(\mathrm{C}_{2} \mathrm{H}_{6}\right)$, benzene $\left(\mathrm{C}_{6} \mathrm{H}_{6}\right)$ hydrogen sulfide $\left(\mathrm{H}_{2} \mathrm{~S}\right)$, sulfur dioxide $\left(\mathrm{SO}_{2}\right)$, carbonyl sulfide $(\mathrm{COS})$, ammonia $\left(\mathrm{NH}_{3}\right)$, nitrogen $\left(\mathrm{N}_{2}\right)$, hydrogen cyanide $(\mathrm{HCN})$, nitrous oxide $\left(\mathrm{N}_{2} \mathrm{O}\right)$, methane $\left(\mathrm{CH}_{4}\right)$, acetylene $\left(\mathrm{C}_{2} \mathrm{H}_{2}\right)$, and ethylene $\left(\mathrm{C}_{2} \mathrm{H}_{4}\right)$. Their concentration can vary depending on the biomass source, but can range from ppm to up to $15 \%[20,21]$. Many studies have been conducted on the effect of syngas impurities on different acetogenic bacteria, but most of them dealt with single impurities, rather than the complex mixture found in real biomass-derived syngas [21-24]. Some groups already did tests with biomass-derived syngas, although in most cases with just one type of such syngas $[18,23,25,26]$. Besides, the reported impact of the impurities has been heterogeneous, thus a generalization is not straightforward [21]. Since the cleaning and removal of the impurities represents an important part of the gasification costs, it is of crucial importance to assess the extent of the cleaning needed for syngas fermentation [27]. Studies performed for the cleaning of syngas which is intended to be used in traditional chemical applications cannot be directly extrapolated in this case, due to the differences mentioned above.

Due to the reasons stated above, the in-depth study of how impurities, gas composition, and different biomass sources affect the fermentation process and its outcomes is of great relevance. Varying biomass composition, as well as seasonal oscillations, are to be expected. Is the fermentation outcome of biomass-derived syngas affected mainly by the $\mathrm{CO}, \mathrm{CO}_{2}$, and $\mathrm{H}_{2}$ composition, as it is in the case of clean syngas, or will the impurities play a bigger role? Answering this question is of great importance if an integrated bio-refinery concept is to be established. A fermentation system where a first screening can be performed, in an easy and rapid manner can definitively help tackling this matter. 
In this study, a syngas fermentation screening system is used to detect and compare the differences between several biomass-derived syngases, as well as model, clean syngases (commercially mixed, and free of impurities). Three biomass-derived syngases have been compared side-by-side to clean, commercially mixed ones, which contained the same composition minus the impurities. As well, four different compositions of clean syngas were tested, from which two had been mixed to match the composition of two different gasification processes. The examination of the gas usage, product formation and growth, as well as yields, productivities, and product distribution profiles allowed for a complete overview of the impact of the different syngases in this particular system, making this system a valuable assessment tool for the evaluation of biomass-derived syngases as fermentation substrate.

\section{Materials and Methods}

\subsection{Microorganism, Medium and Fermentation Conditions}

The microorganism used in all fermentations was C. ljungdahlii DSM 13528. Both the pre-cultures and the fermentation media were based on the one described by Tanner [28]. It contained MES (2-(N-morpholino) ethanesulfonic acid) as buffer, and the $\mathrm{pH}$ was adjusted to 5.9 before autoclaving.

Pre-cultures for each experiment were freshly prepared from a single glycerol stock, stored at $-80{ }^{\circ} \mathrm{C}$. Its full content was transferred to a $100 \mathrm{~mL}$ serum flask containing $50 \mathrm{~mL}$ of medium, with $10 \mathrm{~g} / \mathrm{L}$ of fructose as carbon source, and was grown for $48 \mathrm{~h}$ at $37^{\circ} \mathrm{C}$. Two subsequent passages were performed, following the same procedure described, using a $10 \%$ inoculum. For the last passage, three $250 \mathrm{~mL}$ serum flasks, containing $150 \mathrm{~mL}$ final medium, were inoculated, one for each fermenter. The fermenters were all inoculated simultaneously with a $10 \%$ inoculum volume, using the full content $(150 \mathrm{~mL})$ of one of the $250 \mathrm{~mL}$ serum flasks for each fermenter. This is described in more detail elsewhere, including the specific composition of the medium [29].

\subsection{Experimental Set-Up}

All experiments were conducted in triplicates $(n=3)$. The fermentation time for all set-ups was approximately $93 \mathrm{~h}$.

The syngas used for set-ups 1 and 3 was derived from gasified straw, and was produced and bottled at the Bioliq ${ }^{\circledR}$ plant at KIT, Germany [30]. Set-ups 2 and 4 used a commercially-mixed, clean syngas mixture which replicated the composition of the Bioliq ${ }^{\circledR}$ syngas. The impurities of the biomass-derived Bioliq ${ }^{\circledR}$ syngas were reported to be: $\mathrm{CH}_{4}(0 \%), \mathrm{CH}_{3} \mathrm{OH}(0 \%), \mathrm{HCl}(0 \mathrm{ppm}), \mathrm{HCN}(0.91 \mathrm{ppm}), \mathrm{NH}_{3}$ (150 ppm), $\mathrm{H}_{2} \mathrm{~S}$ (54.1 ppb), COS (12.3 ppb). The analysis was done before $\mathrm{CO}_{2}$ cleaning.

Set-ups 5 and 6 used clean, commercially-mixed syngas. These mixtures mimicked the composition of the syngas produced from the gasification of beech wood or lignin, respectively, at the MILENA indirect gasifier at TNO Energy Transition, Biomass and Energy Efficiency Unit, The Netherlands [13], but no $\mathrm{CH}_{4}$ was included in the mixture. The composition of the two original biomass-derived syngases produced at the MILENA plant, its impurities and the outcome of its fermentation can be found in Liakakou, Infantes et al. [31]. Set-ups 5 and 6 were performed under the same conditions as the beech wood and lignin biomass-derived syngas, respectively.

The syngas used for set-ups 7 and 8 was clean, commercially-mixed. For set-up 7, its composition was based on the syngas resulting from the gasification of lignin at $850{ }^{\circ} \mathrm{C}$ after limestone cleaning, at LNEG (National Laboratory of Energy and Geology), Portugal [32,33]. For set-up 8, the composition was equivalent to that of the syngas obtained by an updraft gasifier of lignin both using oxygen and steam as gasification agents, at the ENEA Research Centre of Trisaia, Italy [32]. Both the original biomass-derived syngas on which set-ups 7 and 8 are based contained only a small amount of $\mathrm{N}_{2}$. This means that the standard off-gas analysis, as described elsewhere [34], would not be possible, since $\mathrm{N}_{2}$ is used in this fermentation system to calculate the total flow rate in the off-gas. The syngas from LNEG and ENEA contained $\mathrm{CH}_{4}$, and since it has been proven to be inert [31] and can be easily 
detected by GC analysis, $\mathrm{CH}_{4}$ was included in the custom-made gas mixture and used in place of $\mathrm{N}_{2}$ to calculate the off-gas flow rate in the same manner.

Two other theoretical, clean syngas compositions were evaluated in set-up 9 and 10, named here

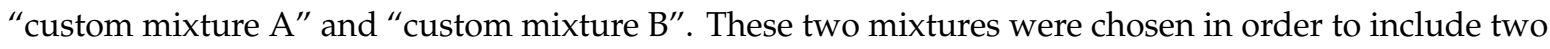
clean gases with a lower $\mathrm{H}_{2}$ content, and different $\mathrm{CO}_{2}: \mathrm{CO}$ ratios, to be able to compare between a wider range of syngas compositions. The composition was chosen to be in accordance with a possible syngas obtained from the gasification of biomass.

Figure 1 shows a schematic representation of the fermentations performed in this work.

\begin{tabular}{|c|c|c|}
\hline \multicolumn{2}{|c|}{ Comparison between biomass-derived and clean syngas } & Clean syngas - composition effect \\
\hline - Biomass-derived & - Clean syngas & - Based on real gasification products \\
\hline Bioliq" (KIT): straw & Clean "Bioliq"-like" & 7 - LNEG (Portugal) \\
\hline 1 - low flow & 2 - clean, low flow & 8 - ENEA (Italy) \\
\hline 3 - high flow & 4 - clean, high flow & $\begin{array}{l}\text { - Custom clean mixtures with identical } \mathrm{H}_{2} \text { but varying } \\
\mathrm{CO} / \mathrm{CO}_{2}\end{array}$ \\
\hline TNO (Netherlands) & $\underline{\text { Clean "TNO-like" }}$ & 9 - Custom mixture A \\
\hline beech wood [31] & 5 - clean, "beech wood-like" & 10 - Custom mixture B \\
\hline lignin [31] & 6 - clean, “lignin-like” & \\
\hline
\end{tabular}

Figure 1. Schematic representation of the experiments performed. Each biomass-derived syngas was compared to clean syngas containing the same composition, but without the impurities (set-ups 1 to 6). The arrows denote pairs of fermentations that were compared side-by-side. Fermentations performed with biomass-derived syngas from TNO Energy Transition, Biomass and Energy Efficiency Unit, the Netherlands, were described elsewhere [31]. Different clean syngases were also tested individually (set-ups 7 to 10), in order to assess the effect of the clean syngas composition on the fermentation outcome. All clean syngases were commercially-mixed, containing only $\mathrm{CO}, \mathrm{CO}_{2}, \mathrm{H}_{2}$ and $\mathrm{N}_{2}$. In the case of set-ups 7 and 8 , it additionally contained $\mathrm{CH}_{4}$.

\subsection{Analytical Methods}

For the fermenters' off-gas analysis, a GC-2010 Plus AT gas chromatograph (GC) (Shimadzu, Kyoto, Japan), with a ShinCarbon ST 80/100 Column ( $2 \mathrm{~m} \times 0.53 \mathrm{~mm}$ ID, Restek, Germany) and an Rtx-1 capillary column ( $1 \mu \mathrm{m}, 30 \mathrm{~m} \times 0.25 \mathrm{~mm}$ ID, Restek, Bad Homburg, Germany) was used.

Four sampled were obtained from each fermenter daily, at 2-3 h intervals, with no samples collected overnight. From this samples, optical density (OD), and acetate and ethanol concentration were determined. Moreover, to detect any left-over fructose, this was also measured during the first $24 \mathrm{~h}$. $\mathrm{pH}$ was measured on-line.

Detailed explanations for the analytical procedures and product formation parameters calculations can be found elsewhere [29].

\subsection{Gas Flow Rate Setting}

Due to the differing gas composition of the gases tested, not all parameters could be kept constant simultaneously. Table 1 shows the average composition and the gas flow fed into the fermenter for all syngases. The values are given as the measured off-gas composition by the on-line GC after the reactor reached equilibrium and under abiotic conditions (before inoculation). At that point, the gas flow fed into the fermenter equals that which comes out at the off-gas.

To enable a comparison between them, the gas flow rate was adapted in each fermentation, in order to have a fixed molar carbon flow or hydrogen carbon flow. 
Table 1. Composition of the gas, flow rate, and amount of substance fed for each set-up. The bioreactors were sparged with each gas before inoculation for at least $3 \mathrm{~h}$. The syngas composition is given based on the average of the values detected in the off-gas measured during this time, after reaching equilibrium conditions in the fermenter. In all cases, apart from $\mathrm{CO}, \mathrm{CO}_{2}, \mathrm{H}_{2}$, and $\mathrm{CH}_{4}$, the remaining component of the syngas is $\mathrm{N}_{2}$. $\mathrm{C}_{\mathrm{in}}$ refers to the sum of the amount of $\mathrm{CO}_{\text {and }} \mathrm{CO}_{2}$. All fermentations were done as triplicates $(n=3)$, and the values given here are the corresponding averages. The syngas custom mixtures which were prepared with the same composition as biomass-derived syngas are marked as such, with the source of the syngas they were based on in brackets. TNO BW: syngas produced at TNO from beech wood; TNO LS: syngas produced at TNO from lignin; LNEG: syngas produced at LNEG, gasification at $850{ }^{\circ} \mathrm{C}$, with limestone treatment; ENEA: syngas produced at ENEA, gasification using $\mathrm{O}_{2}$ and steam. Dashes (-) indicate substances not present in the mixture.

\begin{tabular}{|c|c|c|c|c|c|c|c|c|c|c|c|}
\hline \multicolumn{2}{|c|}{ Syngas Source } & Bioliq ${ }^{\circledR}$-Straw & $\begin{array}{c}\text { Custom } \\
\text { Mixture } \\
\text { (Bioliq }{ }^{\circledR} \text { ) }\end{array}$ & Bioliq ${ }^{\circledR}$-Straw & $\begin{array}{c}\text { Custom } \\
\text { Mixture } \\
\text { (Bioliq }{ }^{\circledR} \text { ) }\end{array}$ & $\begin{array}{c}\text { Custom } \\
\text { Mixture } \\
\text { (TNO BW) }\end{array}$ & $\begin{array}{c}\text { Custom } \\
\text { Mixture } \\
\text { (TNO LS) }\end{array}$ & $\begin{array}{l}\text { Custom } \\
\text { Mixture } \\
\text { (LNEG) }\end{array}$ & $\begin{array}{l}\text { Custom } \\
\text { Mixture } \\
\text { (ENEA) }\end{array}$ & $\begin{array}{l}\text { Custom } \\
\text { Mixture A }\end{array}$ & $\begin{array}{l}\text { Custom } \\
\text { Mixture B }\end{array}$ \\
\hline \multicolumn{2}{|c|}{ Impurities } & Yes & No & Yes & No & No & No & No & No & No & No \\
\hline \multicolumn{2}{|c|}{ Set-up } & 1 & 2 & 3 & 4 & 5 & 6 & 7 & 8 & 9 & 10 \\
\hline \multirow{4}{*}{$\begin{array}{c}\text { Syngas } \\
\text { composition } \\
\text { [vol-\%] }\end{array}$} & $\mathrm{CO}$ & 28.8 & 29.8 & 28.9 & 29.2 & 27.0 & 21.3 & 26.1 & 26.7 & 32.5 & 21.2 \\
\hline & $\mathrm{CO}_{2}$ & 2.8 & 2.6 & 2.8 & 2.7 & 18.3 & 20.6 & 16.7 & 26.4 & 11.9 & 13.7 \\
\hline & $\mathbf{H}_{2}$ & 29.5 & 29.1 & 28.4 & 28.3 & 23.3 & 25.4 & 30.4 & 34.5 & 21.9 & 21.9 \\
\hline & $\mathrm{CH}_{4}$ & - & - & - & - & - & - & 18.9 & 5.3 & - & - \\
\hline \multicolumn{2}{|c|}{ Gas flow rate $[\mathrm{mL} / \mathrm{min}]$} & 26.3 & 26.3 & 18.0 & 18.0 & 18.0 & 23.0 & 20.0 & 16.0 & 18.0 & 23.0 \\
\hline \multicolumn{2}{|c|}{$\mathrm{C}_{\mathrm{in}}\left(\mathrm{CO}_{2}+\mathrm{CO}\right)[\mathrm{mmol} / \mathrm{min}]$} & 0.37 & 0.38 & 0.25 & 0.26 & 0.37 & 0.43 & 0.38 & 0.38 & 0.36 & 0.36 \\
\hline \multicolumn{2}{|c|}{$\mathrm{H}_{2, \text { in }}[\mathrm{mmol} / \mathrm{min}]$} & 0.35 & 0.34 & 0.23 & 0.23 & 0.19 & 0.26 & 0.27 & 0.25 & 0.18 & 0.23 \\
\hline \multicolumn{2}{|c|}{$\mathrm{CO}_{\text {in }}[\mathrm{mmol} / \mathrm{min}]$} & 0.34 & 0.35 & 0.23 & 0.23 & 0.22 & 0.22 & 0.23 & 0.19 & 0.26 & 0.22 \\
\hline \multicolumn{2}{|c|}{$\mathrm{CO}_{2, \text { in }}[\mathrm{mmol} / \mathrm{min}]$} & 0.03 & 0.03 & 0.02 & 0.02 & 0.15 & 0.21 & 0.15 & 0.19 & 0.10 & 0.14 \\
\hline \multicolumn{2}{|c|}{$\mathrm{CH}_{4, \text { in }}[\mathrm{mmol} / \mathrm{min}]$} & - & - & - & - & - & - & 0.18 & 0.04 & - & - \\
\hline \multirow{4}{*}{ Impurities } & HCN [ppm] & 0.91 & - & 0.91 & - & - & - & - & - & - & - \\
\hline & $\mathrm{NH}_{3}[\mathrm{ppm}]$ & 150 & - & 150 & - & - & - & - & - & - & - \\
\hline & $\mathrm{H}_{2} \mathrm{~S}[\mathrm{ppb}]$ & 54.1 & - & 54.1 & - & - & - & - & - & - & - \\
\hline & COS [ppb] & 12.3 & - & 12.3 & - & - & - & - & - & - & - \\
\hline
\end{tabular}


Both the flow of carbon or $\mathrm{H}_{2}$ fed were established and chosen as standard conditions in previous experiments developed in this group [35]. There, a standard fermentation was established with a syngas containing $32.5 \% \mathrm{CO}, 16 \% \mathrm{CO}_{2}$, and $32.5 \% \mathrm{H}_{2}$ (rest $\mathrm{N}_{2}$ ), and $18 \mathrm{~mL} / \mathrm{min}$ as the gas flow. The total molar carbon flow $\left(\mathrm{C}_{\mathrm{in}}\right.$, the sum of $\mathrm{CO}_{2}$ and $\mathrm{CO}$ ) was $0.4 \mathrm{mmol} / \mathrm{min}$, and the total molar hydrogen flow, $0.26 \mathrm{mmol} / \mathrm{min}$ [35]. Here, for all experiments, except for set-ups 3 and 4 (Table 1) the total molar flow of carbon fed into the fermenter was $0.4 \mathrm{mmol} / \mathrm{min}$. In set-ups 3 and 4 , to evaluate the effect of lowering the carbon flow, but maintaining the $\mathrm{H}_{2}$ flow, the total gas flow was adjusted so that the molar flow of $\mathrm{H}_{2}$ fed into the fermenter $\left(\mathrm{H}_{2, \text { in }}\right)$ was $0.26 \mathrm{mmol} / \mathrm{min}$.

\section{Results}

All results are given as the average of a triplicate experiment $(n=3)$.

Product yields (acetic acid and ethanol) to total substrate fed $\left(\mathrm{Y}_{\mathrm{P} / \mathrm{S} \text {, fed }}\right)$, to used substrate $\left(\mathrm{Y}_{\mathrm{P} / \mathrm{S} \text {, used }}\right)$, and to substrate fixed $\left(\mathrm{Y}_{\mathrm{P} / \mathrm{S}}\right.$, fixed $)$ calculated up to the endpoint are shown in Table 2. For the standard deviations, refer to Table S1.

Table 2. Fermentation outcomes, yields, and productivities for the complete run. $\mathrm{Y}_{\mathrm{P} / \mathrm{S}},[\mathrm{g} / \mathrm{g}]=$ gram of products (acetate and ethanol) formed per gram of substrate $\left(\mathrm{CO}, \mathrm{CO}_{2}\right.$, and $\left.\mathrm{H}_{2}\right)$. This has been calculated per grams of substrate fed, used, and fixed. $\mathrm{Y}_{\mathrm{P} / \mathrm{X}}[\mathrm{g} / \mathrm{g}]=$ gram of product (acetate and ethanol) per gram of biomass (cell dry weight). $\mathrm{E}_{\mathrm{C} \text {, total }}[\mathrm{mol} \%]=$ percentage of carbon fixed, as the sum of $\mathrm{CO}_{\text {used }}$ and $\mathrm{CO}_{2}$, used per total carbon fed $\left(\mathrm{CO}_{\text {fed }}\right.$ plus $\left.\mathrm{CO}_{2, \text { fed }}\right)$. Values are given as the average of a triplicate $(n=3)$. Total productivity includes all measured products, that is, ethanol and acetate. For standard deviations, please see Supplementary Table S1.

\begin{tabular}{|c|c|c|c|c|c|c|c|c|c|c|c|}
\hline \multicolumn{2}{|c|}{ Set-Up } & 1 & 2 & 3 & 4 & 5 & 6 & 7 & 8 & 9 & 10 \\
\hline \multicolumn{2}{|c|}{$\mathrm{Y}_{\mathrm{P} / \mathrm{S} \text {, used }}[\mathrm{g} / \mathrm{g}]$} & 0.54 & 0.68 & 0.77 & 0.80 & 0.87 & 0.95 & 0.85 & 0.82 & 0.72 & 0.87 \\
\hline \multicolumn{2}{|c|}{$\mathrm{Y}_{\mathrm{P} / \mathrm{S}, \text { fed }}[\mathrm{g} / \mathrm{g}]$} & 0.29 & 0.43 & 0.46 & 0.38 & 0.38 & 0.34 & 0.38 & 0.36 & 0.38 & 0.38 \\
\hline \multicolumn{2}{|c|}{$Y_{P / S}$ fixed $[g / g]$} & 0.93 & 0.99 & 0.91 & 0.98 & 0.92 & 0.96 & 0.88 & 0.82 & 0.91 & 0.96 \\
\hline \multicolumn{2}{|c|}{$\mathrm{V}_{\text {gas, fed }}[\mathrm{L}]$} & 147 & 148 & 100 & 101 & 100 & 129 & 112 & 91 & 100 & 128 \\
\hline \multicolumn{2}{|c|}{ acetate: ethanol [mol] } & 2.35 & 5.25 & 3.43 & 15.90 & 16.63 & 8.29 & 7.38 & 9.16 & 11.92 & 8.00 \\
\hline \multirow{2}{*}{$\begin{array}{l}\text { Productivity } \\
{[\mathrm{g} / \mathrm{L} \cdot \mathrm{h}]}\end{array}$} & Acetate & 0.10 & 0.18 & 0.12 & 0.12 & 0.19 & 0.20 & 0.19 & 0.19 & 0.17 & 0.18 \\
\hline & Ethanol & 0.03 & 0.03 & 0.03 & 0.001 & 0.01 & 0.02 & 0.02 & 0.02 & 0.01 & 0.02 \\
\hline
\end{tabular}

The same parameters mentioned but calculated up to the point when maximum CO fixation ended, are given in Table 3. In Table S2 the standard deviations for all values are included. 
Table 3. Fermentation outcomes, yields, and productivities calculated up to the point when maximum $\mathrm{CO}$ fixation stopped. $\left.\mathrm{Y}_{\mathrm{P} / \mathrm{S}}, \mathrm{g} / \mathrm{g}\right]=$ gram of products (acetate and ethanol) formed per gram of substrate $\left(\mathrm{CO}, \mathrm{CO}_{2}\right.$, and $\left.\mathrm{H}_{2}\right)$. This has been calculated per grams of substrate fed, used, and fixed. $\mathrm{Y}_{\mathrm{P} / \mathrm{X}}[\mathrm{g} / \mathrm{g}]$ = gram of product (acetate and ethanol) per gram of biomass (cell dry weight). $\mathrm{E}_{\mathrm{C} \text {, total }}[\mathrm{mol} \%]=$ percentage of carbon fixed, as the sum of $\mathrm{CO}_{\text {used }}$ and $\mathrm{CO}_{2}$, used per total carbon fed $\left(\mathrm{CO}_{\text {fed }}\right.$ plus $\left.\mathrm{CO}_{2, \text { fed }}\right)$. Values are given as the average of a triplicate $(n=3)$. Total productivity includes all measured products, that is, ethanol and acetate. Set-ups 1 and 2 did not achieve a CO fixation above $85 \%$ and are therefore not included here. For standard deviations, please see Table S2. A yield slightly above 1 is deemed the result of small analytical inexactitude.

\begin{tabular}{|c|c|c|c|c|c|c|c|c|c|}
\hline \multicolumn{2}{|c|}{ Set-Up } & 3 & 4 & 5 & 6 & 7 & 8 & 9 & 10 \\
\hline \multicolumn{2}{|c|}{$\mathrm{Y}_{\mathrm{P} / \mathrm{S}, \text { used }}[\mathrm{g} / \mathrm{g}]$} & 0.83 & 0.88 & 0.89 & 0.95 & 0.93 & 0.82 & 0.83 & 0.87 \\
\hline \multicolumn{2}{|c|}{$Y_{P / S}$ fed $[g / g]$} & 0.44 & 0.61 & 0.38 & 0.35 & 0.41 & 0.39 & 0.38 & 0.37 \\
\hline \multicolumn{2}{|c|}{$\mathrm{Y}_{\mathrm{P} / \mathrm{S}, \text { fixed }}[\mathrm{g} / \mathrm{g}]$} & 0.98 & 1.03 & 0.93 & 0.95 & 0.93 & 0.82 & 0.99 & 0.90 \\
\hline \multicolumn{2}{|c|}{$\mathrm{Y}_{\mathrm{P} / \mathrm{X}}[\mathrm{g} / \mathrm{g}]$} & 13.82 & 15.24 & 21.67 & 24.24 & 21.34 & 21.73 & 15.34 & 20.38 \\
\hline \multicolumn{2}{|c|}{$\mathbf{V}_{\text {gas, fed }}[\mathbf{L}]$} & 79 & 52 & 77 & 103 & 87 & 71 & 55 & 93 \\
\hline \multicolumn{2}{|c|}{ acetate: ethanol [mol] } & 3.45 & 17.20 & 31.81 & 11.60 & 12.07 & 14.89 & 45.20 & 12.39 \\
\hline \multirow{3}{*}{$\begin{array}{l}\text { Productivity } \\
\text { [g/L·h] }\end{array}$} & Acetate & 0.12 & 0.20 & 0.20 & 0.21 & 0.22 & 0.21 & 0.19 & 0.18 \\
\hline & Ethanol & 0.03 & 0.01 & 0.01 & 0.01 & 0.01 & 0.01 & 0.003 & 0.01 \\
\hline & Total & 0.15 & 0.21 & 0.20 & 0.23 & 0.23 & 0.23 & 0.19 & 0.20 \\
\hline \multicolumn{2}{|c|}{$\mathrm{E}_{\mathrm{C}, \text { total }}[\mathrm{mol} \%]$} & 49.33 & 61.07 & 48.04 & 43.27 & 52.31 & 52.68 & 44.72 & 47.35 \\
\hline
\end{tabular}

$\mathrm{CO}, \mathrm{CO}_{2}$, and $\mathrm{H}_{2}$ usage and $\mathrm{CO}$ fixation profiles for all set-ups are shown in Figure 2. Figure S1 shows the full profile of the gas usage and fixation for set-ups 1 to 4 .

\subsection{Comparison between Biomass-Derived and Impurity-Free Syngas}

\subsubsection{Bioliq ${ }^{\circledR}$ Syngas, Set-Ups 1 and 2}

\section{Substrate Usage and Carbon Fixation}

In set-up 1, which used Bioliq ${ }^{\circledR}$ syngas containing impurities at a gas flow rate of $26.3 \mathrm{~mL} / \mathrm{min}$ (Table 1), the culture presents a lag phase lasting $8 \mathrm{~h}$, after which CO usage started (Figure $2 \mathrm{~A}$ ).

Maximum CO usage (that is, when less than $0.05 \mathrm{mmol} / \mathrm{min} \mathrm{CO}$, corresponding to $85 \%$ of $\mathrm{CO}$ usage, is detected in the off-gas) started $35 \mathrm{~h}$ after inoculation. It lasted for $34 \mathrm{~h}$ (Figure $3 \mathrm{~A}$ ). $\mathrm{H}_{2}$ usage started only after $23 \mathrm{~h}$, when the off-gas flow of CO was $0.19 \pm 0.09 \mathrm{mmol} / \mathrm{min}$. The lowest flow of $\mathrm{H}_{2}$ detected in the off-gas was $0.13 \pm 0.02 \mathrm{mmol} / \mathrm{min}$ at $47 \mathrm{~h}$, corresponding to $62.20 \pm 6.27 \%$ usage. This can be seen in Figures $1 \mathrm{~A}$ and $2 \mathrm{~A}$. 


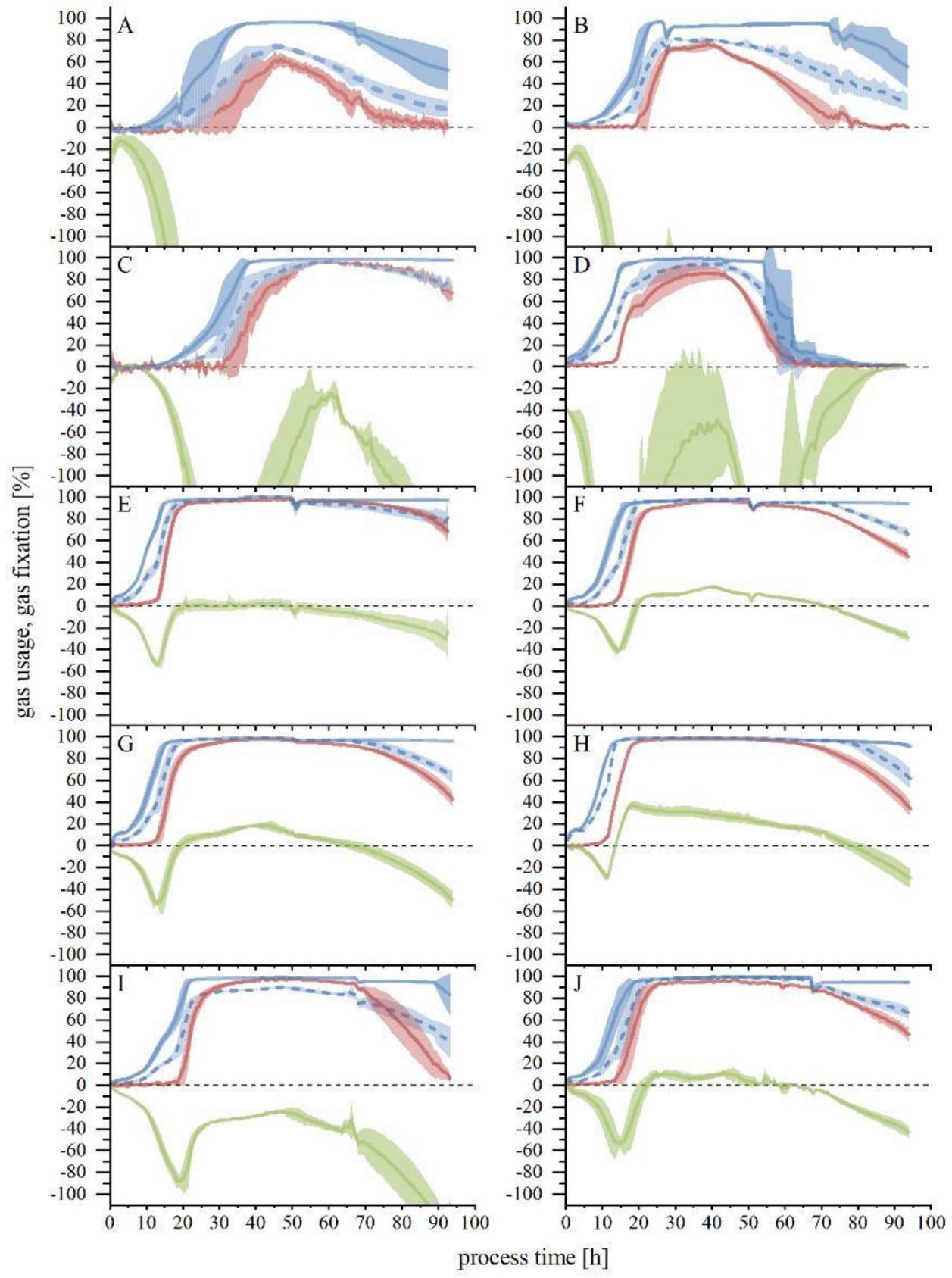

$$
-\mathrm{H}_{2} \text { usage }-\mathrm{CO} \text { usage }-\mathrm{CO}_{2} \text { usage }---\mathrm{CO} \text { fixation }
$$

Figure 2. Substrate usage and fixation for set-ups 1 to 10. (A) to (J), in alphabetical order, refer to each individual set-up, in numerical ascending order-(A) is set-up 1, (B) is set-up 2, etc. Usage is for $\mathrm{H}_{2}$ (red line), $\mathrm{CO}_{2}$ (green line), and $\mathrm{CO}$ (blue line). $\mathrm{CO}$ fixation is depicted by the dotted blue line. The calculated difference between amount of substance flow rate fed into the bioreactor and the amount of substance flow rate detected in the off-gas is shown here as a percentage. For CO fixation, if the $\mathrm{CO}_{2}$ usage was negative, the amount of $\mathrm{CO}_{2}$ produced was subtracted from the amount of (perceived) CO used. Lines show the average of a triplicate $(n=3)$, while the lighter colored areas depict the standard deviation. 


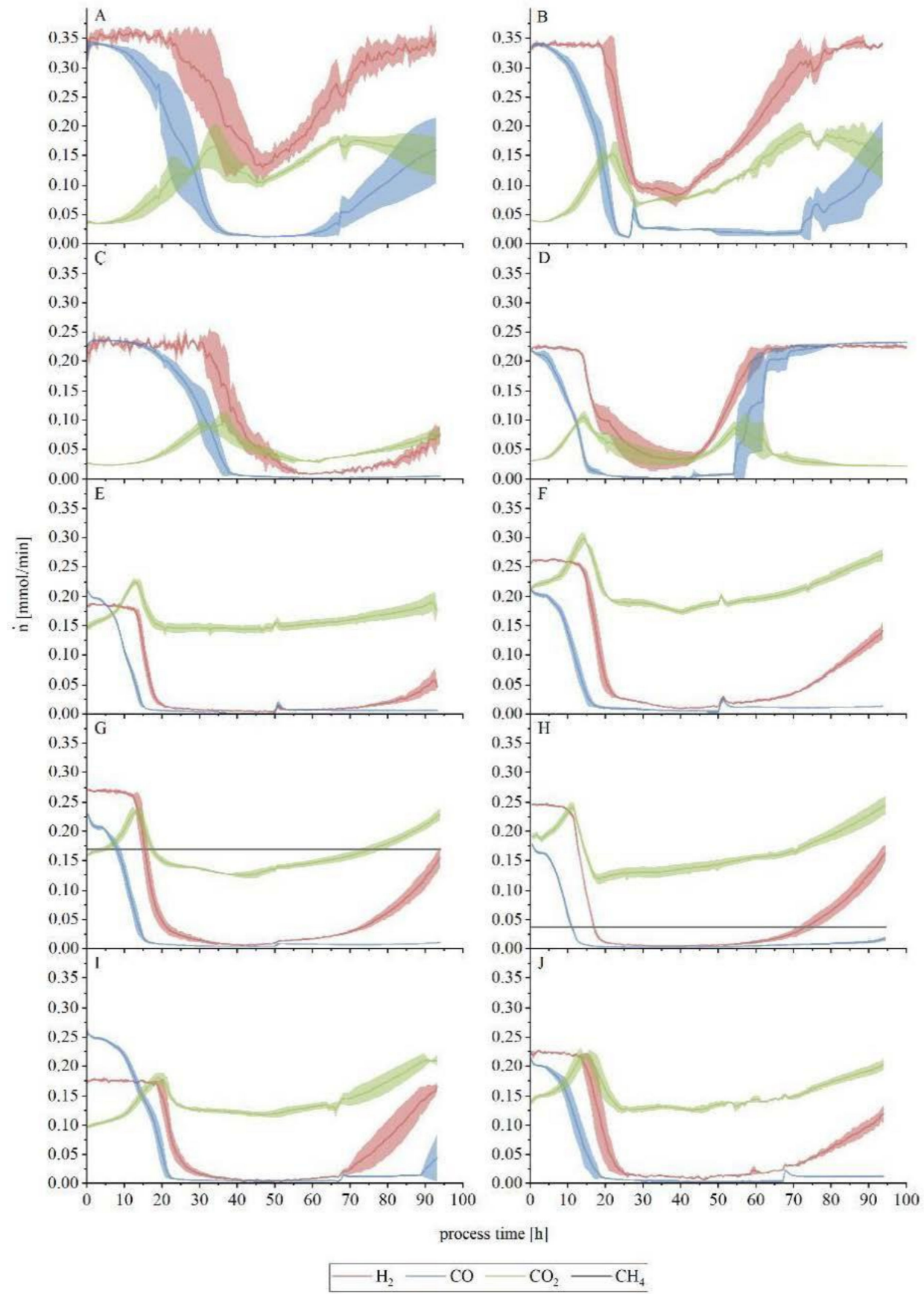

Figure 3. Off-gas profile for set-ups 1 to 10. (A) to (J), in alphabetical order, refer to each individual set-up, in numerical ascending order-(A) is set-up 1, (B) is set-up 2, etc. The molar flow rate is shown here, as obtained from the measurements of the on-line GC, for $\mathrm{H}_{2}$ (red line), $\mathrm{CO}_{2}$ (green line) and $\mathrm{CO}$ (blue line). Lines show the average of a triplicate $(n=3)$, while the lighter colored areas depict the standard deviation.

No $\mathrm{CO}_{2}$ usage was detected at any point; on the contrary, it was produced throughout the fermentation (Figure 3A). This affected the maximum $\mathrm{CO}$ fixation obtained, since it stayed above $70 \%$ for only $7 \mathrm{~h}$, reaching its maximum value $(74.14 \pm 2.89 \%)$ at $47 \mathrm{~h}$, simultaneously to the highest consumption of $\mathrm{H}_{2}$. The percentage of carbon fixed in products and biomass $\left(\mathrm{E}_{\mathrm{C}, \text { total }}\right)$ at the end of the run was $30.95 \pm 2.05 \mathrm{~mol} \%$ (Table 2). 
No maximum overall usage was detected during the fermentation. This term describes the interval during which the sum of $\mathrm{CO}, \mathrm{CO}_{2}$, and $\mathrm{H}_{2}$ usage combined was above $85 \%$ of the maximum achieved for the whole fermentation [29].

In set-up 2, with the same composition of syngas and at the same flow rate, but without impurities, the lag phase was remarkably shorter, with $\mathrm{CO}$ usage starting almost immediately, after $1.5 \mathrm{~h}$. Maximum CO usage (above $85 \%$ ) also happened earlier in this case, at $22 \mathrm{~h}$ of process-time, and lasted longer: $53 \mathrm{~h}$ (Figure 2B). The same trend is true for $\mathrm{H}_{2}$, whose usage started after $7 \mathrm{~h}$ when the $\mathrm{CO}$ in the off-gas was $0.33 \pm 0.01 \mathrm{mmol} / \mathrm{min}$, which is higher than for the previous experiment. The lowest flow of $\mathrm{H}_{2}$ and the corresponding maximum usage value were $0.08 \pm 0.02 \mathrm{mmol} / \mathrm{min}$ and $75.99 \pm 5.77 \%$, respectively, after $39 \mathrm{~h}$ (Figures $1 \mathrm{~B}$ and $2 \mathrm{~B}$ ).

$\mathrm{CO}_{2}$ usage did not happen in this set-up either (Figure 3B). Here, though, $\mathrm{CO}$ fixation was above $70 \%$ for $30.5 \mathrm{~h}$, four times longer than for the former set-up. Its maximum was attained earlier, at $30 \mathrm{~h}$, with $81.14 \pm 0.29 \%$, slightly before the maximum $\mathrm{H}_{2}$ consumption. $\mathrm{E}_{\mathrm{c}, \text { total }}$ was also higher, as a result of the improved CO fixation: $44.65 \pm 22.23 \mathrm{~mol} \%$ (Table 2).

As with set-up 1, neither here any maximum overall usage was observed.

\section{Biomass, Product Formation, Yield, and Productivity}

As can be observed in Figure 4A, biomass increased continuously during the first $49 \mathrm{~h}$ in the first set-up. A CDW (cell dry weight) of $0.60 \pm 0.12 \mathrm{~g} / \mathrm{L}$ was achieved at that point. Afterwards, growth slowed down and eventually plateaued. Maximum CDW was reached its maximum at $69 \mathrm{~h}$ $(0.71 \pm 0.12 \mathrm{~g} / \mathrm{L})$. Acetate production happened mostly between $20 \mathrm{~h}$ and $73 \mathrm{~h}$.

At $25 \mathrm{~h}$, the acetate concentration was $0.84 \pm 0.34 \mathrm{~g} / \mathrm{L}$, and the highest concentration was detected at $91 \mathrm{~h}(10.27 \pm 1.19 \mathrm{~g} / \mathrm{L})$. Ethanol production was already detected after $21 \mathrm{~h}(0.20 \pm 0.12 \mathrm{~g} / \mathrm{L})$, and it continued to increase throughout the fermentation, up to $3.29 \pm 0.42 \mathrm{~g} / \mathrm{L}$ at the end of the run.

As can be observed in Figure 4A, biomass increased continuously during the first $49 \mathrm{~h}$ in set-up 1 . A CDW (cell dry weight) of $0.60 \pm 0.12 \mathrm{~g} / \mathrm{L}$ was achieved at that point. Afterwards, growth slowed down and eventually plateaued. Maximum CDW was reached at $69 \mathrm{~h}(0.71 \pm 0.12 \mathrm{~g} / \mathrm{L})$. Acetate production happened mostly between $20 \mathrm{~h}$ and $73 \mathrm{~h}$. At $25 \mathrm{~h}$, the acetate concentration was $0.84 \pm 0.34 \mathrm{~g} / \mathrm{L}$, and the highest concentration was detected at $91 \mathrm{~h}(10.27 \pm 1.19 \mathrm{~g} / \mathrm{L})$. Ethanol production was already detected after $21 \mathrm{~h}(0.20 \pm 0.12 \mathrm{~g} / \mathrm{L})$, and it continued to increase throughout the fermentation, up to $3.29 \pm 0.42 \mathrm{~g} / \mathrm{L}$ at the end of the run.

In set-up 2, in the absence of impurities, more biomass could be generated during the first $51 \mathrm{~h}$, with a CDW of $0.72 \pm 0.04 \mathrm{~g} / \mathrm{L}$ at that time point. At $76 \mathrm{~h}$, its measured maximum was met, $0.76 \pm 0.07 \mathrm{~g} / \mathrm{L}$. Thereafter, a decrease in biomass was seen (Figure $4 \mathrm{~B}$ ). Acetate production was faster in this case, with $2.55 \pm 0.48 \mathrm{~g} / \mathrm{L}$ produced after $26.5 \mathrm{~h}$. The final concentration was $16.75 \pm 0.34 \mathrm{~g} / \mathrm{L}$, a $63 \%$ increase compared to set-up 1 . Contrarily, less ethanol was produced, with a final value of $2.47 \pm 0.24 \mathrm{~g} / \mathrm{L}, 25 \%$ less than set-up 1 .

Product yields (acetic acid and ethanol) to total substrate fed $\left(\mathrm{Y}_{\mathrm{P} / \mathrm{S} \text {, fed }}\right)$, to used substrate $\left(\mathrm{Y}_{\mathrm{P} / \mathrm{S} \text {, used }}\right)$, and to substrate fixed $\left(\mathrm{Y}_{\mathrm{P} / \mathrm{S} \text {, fixed }}\right)$ calculated up to the endpoint are shown in Table 2. No values are given up to the point when maximum $\mathrm{CO}$ fixation ended due to the fact that no $\mathrm{CO}$ fixation above $85 \mathrm{~mol} \%$ was detected.

It can be noted that set-up 2 achieved a better performance overall, with higher yields and productivities, except for ethanol. Set-up 1 presented a lower acetate to ethanol ratio $(2.35$ compared to 5.25 in set-up 2), meaning more ethanol was produced per mol of acetate.

$\mathrm{Y}_{\mathrm{P} / \mathrm{X}}$ at the end-point is higher in set-up 2: $32.36 \pm 1.99 \mathrm{~g}_{\text {products }} / \mathrm{g}_{\text {biomass, }}$ compared to $20.51 \pm 1.75 \mathrm{~g}$ products $/ \mathrm{g}_{\text {biomass }}$ for set-up 1, indicating that more grams of product per gram of biomass were formed (Table 2). 

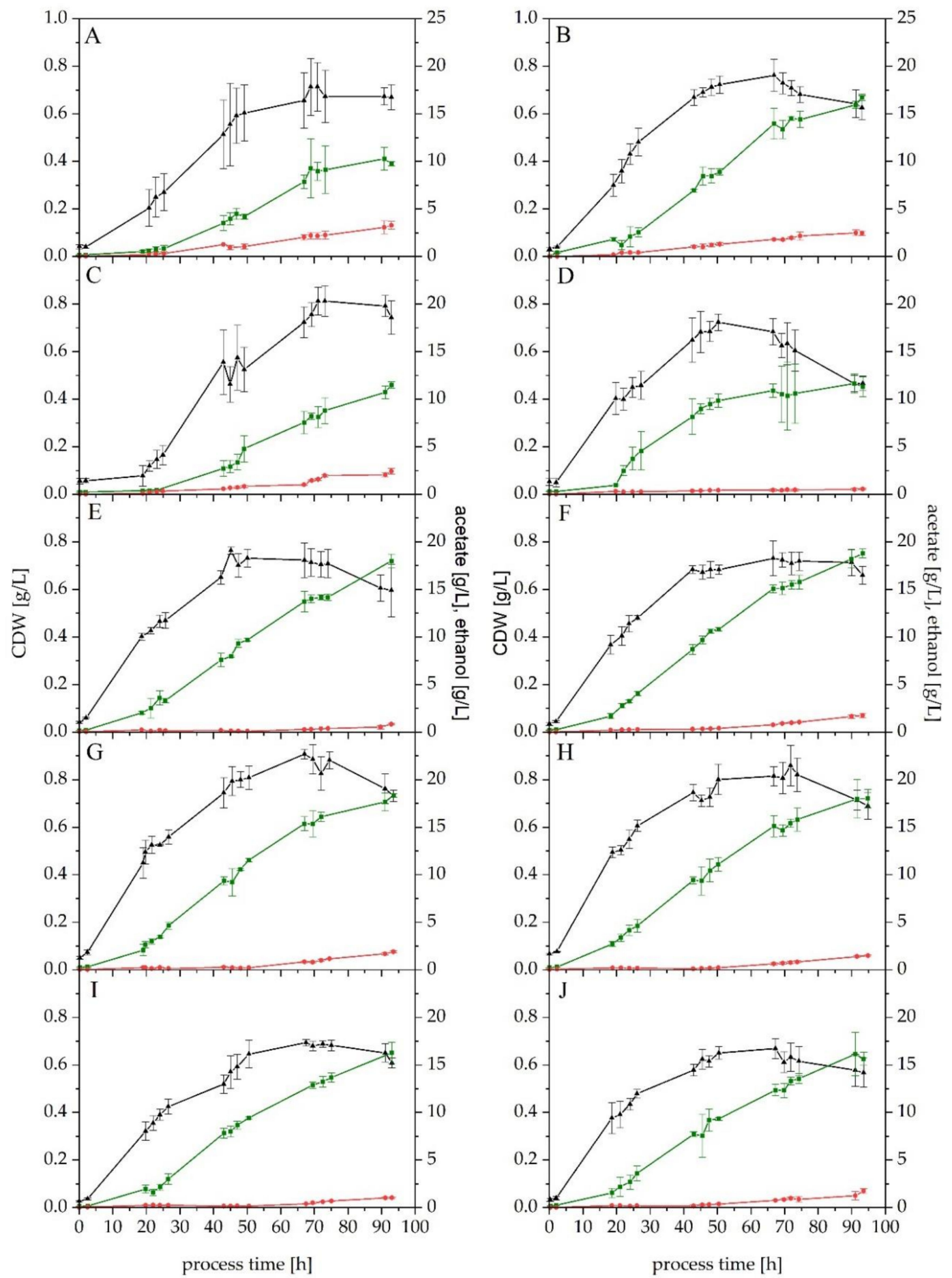

$\mathrm{CDW} \longrightarrow$ acetate $\longrightarrow$ ethanol

Figure 4. Growth and product formation of set-ups 1 to 10. (A) to (J), in alphabetical order, refer to each individual set-up, in numerical ascending order-(A) is set-up 1, (B) is set-up 2, etc. Average values of the triplicates $(n=3)$ for cell dry weight (CDW, black triangles), acetate (green squares) and ethanol (red dots), with standard deviation. Points indicate actual measurements. Lines are only depicted for clarity purposes. 


\subsubsection{Bioliq ${ }^{\circledR}$ Syngas, Set-Ups 3 and 4}

Substrate Usage and Carbon Fixation

In set-up 3, which is analogous to set-up 1 except for the reduced gas flow $(18 \mathrm{~mL} / \mathrm{min}$, Table 1$)$, $\mathrm{CO}$ usage started slightly later, at $10 \mathrm{~h}$ (Figure 2C). Maximum $\mathrm{CO}$ usage started after $35.8 \mathrm{~h}$, similar to set-up 1, but did not stop and lasted until the end of the fermentation.

$\mathrm{H}_{2}$ usage started, in this case, after $31.3 \mathrm{~h}$, a delay of $8 \mathrm{~h}$ compared to set-up 1 . At that moment, the $\mathrm{CO}$ flow in the off-gas was $0.10 \pm 0.05 \mathrm{mmol} / \mathrm{min}$ (Figure 3C). Maximum $\mathrm{H}_{2}$ usage was remarkably higher than set-up $1,96.07 \pm 0.26 \%(0.01 \pm 0.001 \mathrm{mmol} / \mathrm{min}$ in the off-gas $)$, at $59.5 \mathrm{~h}$. For comparison, $\mathrm{H}_{2}$ consumption was already at $61.69 \pm 13.89 \%$ at $41 \mathrm{~h}$, and $79.47 \pm 9.17 \%$ at $47 \mathrm{~h}$ (Figure 2C).

As seen in the previous experiment with lower gas flow, no $\mathrm{CO}_{2}$ usage was detected here either (Figure 3C). Nonetheless, more $\mathrm{CO}$ could be fixed: at $38 \mathrm{~h} \mathrm{CO}$ fixation had already reached $70.91 \pm 13.79 \%$. In contrast to set-up $1, \mathrm{CO}$ fixation above $85 \%$ was detected between $44.5 \mathrm{~h}$ and $82.12 \mathrm{~h}$ (Figure $2 \mathrm{C}$ ). $\mathrm{E}_{\mathrm{C} \text {, total }}$ at the end of the run was, therefore, increased: $52.23 \pm 2.11 \mathrm{~mol} \%$ (Table 2), 69\% higher than its corresponding higher-flow set-up. The maximum overall usage interval, where the sum of $\mathrm{CO}, \mathrm{CO}_{2}$, and $\mathrm{H}_{2}$ combined was above $85 \%$ of the maximum achieved for the whole fermentation, lasted $9 \mathrm{~h}$, from $54.4 \mathrm{~h}$ to $63.2 \mathrm{~h}$ (Table 4 ).

Table 4. Gas consumption profiles. All values given as an average of a triplicate $(n=3)$. Maximum overall usage interval was calculated as the time period where an $85 \%$ of the combined maximum total usage $\left(\mathrm{CO}, \mathrm{CO}_{2}\right.$, and $\left.\mathrm{H}_{2}\right)$ was achieved for each individual fermentation. Similarly, the maximum CO fixation for each experiment was calculated, and the last point where it was above $85 \%$ of this maximum is given as the "time to end of maximum CO fixation." Set-ups 1 and 2 did not reach a value of maximum overall usage above $85 \%$, nor did the $\mathrm{CO}$ fixation rise above that threshold.

\begin{tabular}{cccccccccccc}
\hline & Set-Up & $\mathbf{1}$ & $\mathbf{2}$ & $\mathbf{3}$ & $\mathbf{4}$ & $\mathbf{5}$ & $\mathbf{6}$ & $\mathbf{7}$ & $\mathbf{8}$ & $\mathbf{9}$ & $\mathbf{1 0}$ \\
\hline $\begin{array}{c}\text { Maximum } \\
\text { overall }\end{array}$ & Start [h] & n.a. & n.a. & 54.4 & 34.5 & 18.1 & 21.0 & 21.0 & 16.2 & 28.2 & 22.0 \\
$\begin{array}{c}\text { Esage }[\mathrm{h}] \\
\text { interval }\end{array}$ & n.a. & n.a. & 63.2 & 44.0 & 73.9 & 71.0 & 69.0 & 70.7 & 66.2 & 67.0 \\
$\begin{array}{c}\text { Time to end of maximum } \\
\text { CO fixation }(>\mathbf{8 5 \%})[\mathrm{h}]\end{array}$ & n.a. & n.a. & 8.8 & 9.5 & 55.8 & 50.0 & 48.0 & 54.5 & 38.0 & 45.0 \\
\hline
\end{tabular}

The gas composition for set-up 4 was the same as the one used for set-up 2, emulating the Bioliq ${ }^{\circledR}$ syngas but without any impurity. The gas flow rate was the same as for set-up 3 (Table 1). From this first group of fermentations, this was the one where $\mathrm{CO}$ usage started the earliest: immediately after inoculation. After $15 \mathrm{~h}$, maximum CO usage had been achieved, making this fermentation the fastest here as well. In this instance, though, it behaved similarly to set-up 2, and decreased to $16.17 \pm 7.38 \%$ at $63.08 \mathrm{~h}$, stopping altogether at $80 \mathrm{~h}$ (Figure 2D). It lasted $65 \mathrm{~h}, 12 \mathrm{~h}$ longer than set-up 2. Some $\mathrm{H}_{2}$ usage was observed from the start, averaging to $1.89 \%$ for the first $9 \mathrm{~h}$, reaching $20.06 \pm 5.85 \%$ at $15 \mathrm{~h}$ of process-time, making this the earliest of the 4 set-ups for Bioliq ${ }^{\circledR}$ syngas. Afterwards, it increased steadily and reached higher values than its higher flow counterpart. Values above $85 \%$ usage started at $36 \mathrm{~h}: 85.44 \pm 7.98 \%$, corresponding to $0.03 \pm 0.02 \mathrm{mmol} / \mathrm{min}$ in the off-gas (Figure 3D), with maximum usage lasting for $6 \mathrm{~h}$ (Figure 2D). Its maximum value was $85.73 \pm 6.34 \%$, at $39 \mathrm{~h}$.

In line with the previous runs, no $\mathrm{CO}_{2}$ usage was seen (Figure 3D). Maximum $\mathrm{CO}$ fixation started at $24.5 \mathrm{~h}$ and lasted for $24 \mathrm{~h}$ until process-time at $49 \mathrm{~h}$ (Table 4 ). Even if the maximum CO fixation achieved was higher, interestingly, it stayed above $70 \%$ during $36 \mathrm{~h}$, very similar to set-up 2 . Its maximum, $94.18 \pm 4.68 \%$, at $39 \mathrm{~h}$, happened simultaneously to the maximum $\mathrm{H}_{2}$ usage. $\mathrm{E}_{\mathrm{C} \text {, total }}$ for the complete run was $39.87 \pm 3.14 \mathrm{~mol} \%$, lower than both set-ups 2 and 3 (Table 2). The maximum overall usage interval started $20 \mathrm{~h}$ earlier than in set-up 3, but lasted for a similar period of time, $9.5 \mathrm{~h}$, $0.7 \mathrm{~h}$ longer (Table 4 ). 
Biomass, Product Formation, Yield, and Productivity

Acetate production and biomass growth started in set-up 3 after $19 \mathrm{~h}$, as can be seen in Figure $4 \mathrm{C}$. After $71 \mathrm{~h}$, the maximum CDW was obtained: $0.81 \pm 0.06 \mathrm{~g} / \mathrm{L}$, slowly decreasing after that. After the first $19 \mathrm{~h}$, acetate concentration in the broth increased constantly throughout the fermentation, up to its final value of $12.25 \pm 1.59 \mathrm{~g} / \mathrm{L}$. Ethanol formation started also after $19 \mathrm{~h}$, but its production rate increased at the same time as the growth stopped (Figure $4 \mathrm{C}$ ). By the end of the fermentation, it had slowed down, reaching a final concertation of $2.43 \pm 0.01 \mathrm{~g} / \mathrm{L}$.

Regarding set-up 4, biomass increased faster, reaching $0.40 \pm 0.07 \mathrm{~g} / \mathrm{L}$ at $19 \mathrm{~h}$, steadily rising to its maximum measured, $0.72 \pm 0.04 \mathrm{~g} / \mathrm{L}$ at $50 \mathrm{~h}$. After $66.5 \mathrm{~h}$, a reduction in the CDW concentration was detected, dropping to a final value of $0.47 \pm 0.03 \mathrm{~g} / \mathrm{L}$ (Figure 4D). Even if biomass had increased during the first $19 \mathrm{~h}$, only $0.98 \pm 0.08 \mathrm{~g} / \mathrm{L}$ of acetate was produced. Subsequently, the production of acetate increased and reached the maximum measured concentration of $10.98 \pm 0.71 \mathrm{~g} / \mathrm{L}$ at $66.5 \mathrm{~h}$, when growth had already haltered. Some increase still happened up to the end of the process, albeit slower. The final concentration in the broth was $11.33 \pm 1.03 \mathrm{~g} / \mathrm{L}$. Contrasting with the other three set-ups, just $0.55 \pm 0.09 \mathrm{~g} / \mathrm{L}$ of ethanol was formed in this case.

As mentioned above, in both set-ups 3 and 4 maximum $\mathrm{CO}$ consumption, above $85 \%$, was achieved (Table 4), so in this case yield and productivity are calculated for both the end-point and up to the point where maximum CO fixation stopped, and are shown in Tables 2 and 4.

It can be seen that, as already observed for set-ups 1 and 2, the fermentation with clean syngas, set-up 4, resulted in a much higher acetate to ethanol ratio compared to that of set-up 3, both at the end of the process (Table 2), and up to the point where maximum CO fixation ended (Table 3), being approximately 5 times higher in both cases. Concerning the yields, those of set-up 4 were in all cases above the ones of set-up 3. As for the end-point $\mathrm{Y}_{\mathrm{P} / \mathrm{X}}$, it was higher for set-up 4 $\left(28.09 \pm 2.70 \mathrm{~g}_{\text {product }} / \mathrm{g}_{\text {biomass }}\right.$, against $20.23 \pm 1.32 \mathrm{~g}$ product $/ \mathrm{g}_{\text {biomass }}$ for set-up 3$)$. Up to the point where $\mathrm{CO}$ fixation ended, even if $\mathrm{Y}_{\mathrm{P} / \mathrm{X}}$ was also higher for set-up 4, the difference was much smaller: $13.82 \pm 0.62$ for set-up 3 , and $15.24 \pm 0.41$ for set-up 4 .

\subsubsection{TNO Syngas, Set-Ups 5 and 6}

The results of the fermentation of two biomass-derived syngas, following the gasification of beech wood and lignin at the MILENA gasifier, TNO Energy Transition, Biomass and Energy Efficiency Unit (Netherlands), were shown in Liakakou, Infantes et al. [31]. Some of the results obtained there were: for the beech wood syngas, the maximum CDW obtained was $0.62 \mathrm{~g} / \mathrm{L}$ at $66.5 \mathrm{~h}$; the final acetate and ethanol concentrations were $15.6 \mathrm{~g} / \mathrm{L}$ and $1.6 \mathrm{~g} / \mathrm{L}$, respectively, with a total final productivity of $0.18 \mathrm{~g} / \mathrm{L} \cdot \mathrm{h}$. Final

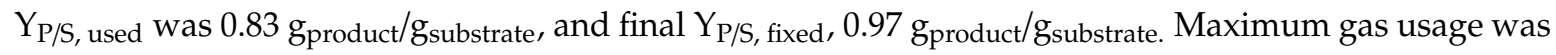
obtained between 17 and $38 \mathrm{~h}$ [31]. Regarding the lignin gas, the maximum CDW was $0.61 \mathrm{~g} / \mathrm{L}$ at $66 \mathrm{~h}$, similar to the beech wood syngas. The final product concentration was $14.9 \mathrm{~g} / \mathrm{L}$ for acetate, and

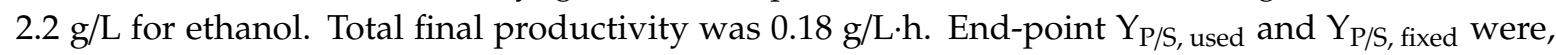
respectively, $0.79 \mathrm{~g}_{\text {product }} / \mathrm{g}_{\text {substrate }}$ and $0.92 \mathrm{~g}$ product $/ \mathrm{g}_{\text {substrate }}$. For this syngas, maximum gas usage was detected between 22 and $48 \mathrm{~h}$ [31].

Below, the results for the fermentations done with the same composition as each of the TNO syngases, but without impurities, are given.

\section{Substrate Usage and Carbon Fixation}

In set-up 5, maximum $\mathrm{CO}$ usage was reached $14 \mathrm{~h}$ after inoculation (Figure 2E), with a detected flow of $\mathrm{CO}$ in the off-gas of $0.03 \pm 0.01 \mathrm{mmol} / \mathrm{min}$ (Figure $3 \mathrm{E}$ ). $3 \mathrm{~h}$ later, at $17 \mathrm{~h}$ of process-time, maximum CO fixation was detected. This lasted for $66 \mathrm{~h}$, averaging $94 \%$. Maximum CO usage lasted until the end of the fermentation.

$\mathrm{H}_{2}$ usage started $9 \mathrm{~h}$ after inoculation of the fermenters, increasing thereafter, and reaching the maximum threshold ( $\geq 85 \%$ ) after $18 \mathrm{~h}$ (Figure $2 \mathrm{E}$ ), when the flow of $\mathrm{H}_{2}$ detected in the off-gas 
had decreased to $0.03 \pm 0.01 \mathrm{mmol} / \mathrm{min}$ (Figure 3E). This maximum usage lasted $67 \mathrm{~h}$, up to $85 \mathrm{~h}$ of process-time, with an average of $95 \%$.

Some marginal $\mathrm{CO}_{2}$ usage was detected between $21 \mathrm{~h}$ and $49 \mathrm{~h}$, with an average of $1 \%$ (Figure 2E).

Between $18 \mathrm{~h}$ and $74 \mathrm{~h}$, maximum overall usage was achieved (Table 4). $\mathrm{E}_{\mathrm{C} \text {,total }}$ for the overall run was $48.79 \pm 2.41 \mathrm{~mol} \%$ (Table 2).

In set-up 6, maximum $\mathrm{CO}$ usage lasted for $79 \mathrm{~h}$, between $15 \mathrm{~h}$ and the end of the fermentation. The maximum CO fixation interval went from $18 \mathrm{~h}$ to $79 \mathrm{~h}$, with an average of $95 \%$ (Figure 2F).

At $22 \mathrm{~h} \mathrm{H}_{2}$ maximum usage started, lasting until $71 \mathrm{~h}$ of process-time. An average of $0.02 \mathrm{mmol} / \mathrm{min}$, or $92 \%$ usage, was detected between those two time points. $\mathrm{CO}_{2}$ usage was detected starting from $20 \mathrm{~h}$ to $71 \mathrm{~h}$, averaging $10 \%$. Its maximum was met at $40 \mathrm{~h}$, when $0.17 \pm 0.01 \mathrm{mmol} / \mathrm{min}$ of $\mathrm{CO}_{2}$ were measured in the off-gas, representing $17.72 \pm 1.50 \%$ usage (Figures $1 \mathrm{~F}$ and $2 \mathrm{~F}$ ).

The interval of maximum overall usage started at $21 \mathrm{~h}$ and ended at $71 \mathrm{~h}$ of process-time (Table 2). The $\mathrm{E}_{\mathrm{C} \text {, total }}$ for the complete run amounted in this case to $43.27 \pm 0.28 \mathrm{~mol} \%$ (Table 2).

Biomass, Product Formation, Yield, and Productivity

Biomass, acetate, and ethanol profiles are shown in Figure $4 \mathrm{E}$ for set-up 5, and Figure $4 \mathrm{~F}$ for set-up 6.

On set-up 5, biomass reached $0.40 \pm 0.01 \mathrm{~g} / \mathrm{L} 19 \mathrm{~h}$ after inoculation. The CDW continued to increase up to $45 \mathrm{~h}$, with an average of $0.71 \mathrm{~g} / \mathrm{L}$ between $42 \mathrm{~h}$ and $50 \mathrm{~h}$. Afterwards, it started to decline, and the final recorded value was $0.60 \pm 0.11 \mathrm{~g} / \mathrm{L}$.

After the first $19 \mathrm{~h}$, acetate was produced at a constant rate throughout the fermentation, reaching a final value of $18.00 \pm 0.74 \mathrm{~g} / \mathrm{L}$. Ethanol, on the other hand, remained below $0.2 \mathrm{~g} / \mathrm{L}$ up to $67 \mathrm{~h}$, when it reached $0.28 \pm 0.05 \mathrm{~g} / \mathrm{L}$. Its final concentration was $0.84 \pm 0.07 \mathrm{~g} / \mathrm{L}$.

The final molar acetate to ethanol ratio for this fermentation was $16.63 \pm 1.71$ (Table 2), while up to the end of maximum CO fixation, it was much higher, $31.82 \pm 2.22 \mathrm{~g} / \mathrm{L}$ (Table 3), as a result of the later start in ethanol formation. The total, final productivity was $0.20 \pm 0.01 \mathrm{~g} / \mathrm{L} \cdot \mathrm{h}$, that the same value as for the productivity calculated up to the end of maximum CO fixation. Regarding the yields, $\mathrm{Y}_{\mathrm{P} / \mathrm{S} \text {, fixed }}$ was very similar for the entire run and up to the end of maximum $\mathrm{CO}$ fixation, with values of $0.92 \pm 0.03 \mathrm{~g}_{\text {product }} / \mathrm{g}_{\text {substrate }}$ and $0.93 \pm 0.02 \mathrm{~g}_{\text {product }} / \mathrm{g}_{\text {substrate, }}$ respectively. $\mathrm{Y}_{\mathrm{P} / \mathrm{X}}$ calculated at the end-point was $34.79 \pm 7.47 \mathrm{~g}_{\text {product }} / \mathrm{g}_{\text {biomass }}$. Up to the end of maximum CO fixation, this was lower, $21.67 \pm 1.19$ g product $/ g_{\text {biomass }}$.

Concerning set-up 6 , the biomass growth followed a similar trend to that of set-up 5 , reaching $0.68 \pm 0.02 \mathrm{~g} / \mathrm{L} 43 \mathrm{~h}$ after inoculation. It then slightly increased to its maximum, $0.73 \pm 0.07 \mathrm{~g} / \mathrm{L}$ at $67 \mathrm{~h}$, remaining mostly constant until $90 \mathrm{~h}$. A decrease in the cell dry weight was noticed in the last sample.

As with set-up 5, acetate was produced during the whole process, but in this case, after $67 \mathrm{~h}$ its production slowed down slightly, coinciding to when the culture stopped growing. A noticeable ethanol production only happened after approximately $50 \mathrm{~h}$, when it reached $0.41 \pm 0.03 \mathrm{~g} / \mathrm{L}$. At $67 \mathrm{~h}$, the ethanol formed amounted to $0.77 \pm 0.11 \mathrm{~g} / \mathrm{L}$, and the final concentration measured was $1.76 \pm 0.23 \mathrm{~g} / \mathrm{L}$, almost $1 \mathrm{~g} / \mathrm{L}$ higher than set-up 6 .

The molar ratio of acetate to ethanol at the end of the process was $8.29 \pm 1.07$, half that of set-up 5. Also, when looking at the ratio obtained up to the end of maximum CO fixation, on set-up 6 it was almost three times lower than set-up 5 (Table 3). The acetate and total productivities for both calculated intervals are comparable to set-up 5, but is not so for ethanol, which were higher, as expected by looking at the product formation mentioned above. Both $\mathrm{Y}_{\mathrm{P} / \mathrm{Sfed}}$ and $\mathrm{Y}_{\mathrm{P} / \mathrm{S} \text {, fixed }}$ are comparable to

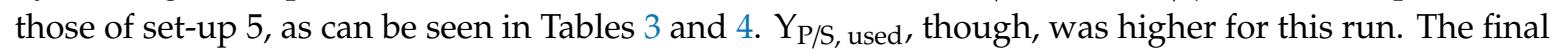
$\mathrm{Y}_{\mathrm{P} / \mathrm{X}}$ equated to $32.54 \pm 1.50 \mathrm{~g}_{\text {product }} / \mathrm{g}_{\text {biomass }}$, very close to that of the previous set-up, and so it was the calculated up to the end of maximum CO fixation, $24.24 \pm 0.77 \mathrm{~g}_{\text {product }} / \mathrm{g}_{\text {biomass }}$. 


\subsubsection{Clean Syngas Fermentations}

\subsubsection{LNEG and ENEA Based Syngas, Set-Ups 7 and 8}

Substrate Usage and Carbon Fixation

In set-up 7, CO usage started directly after inoculation, reaching $85 \%$ at $14 \mathrm{~h}$. Maximum CO fixation started shortly thereafter, at $17 \mathrm{~h}$, and stopped at $80 \mathrm{~h}$. Maximum usage lasted up to the end of the fermentation, and during this time the average flow of CO detected in the off-gas was $0.007 \mathrm{mmol} / \mathrm{min}$, representing a $96.97 \%$ average usage (Figure $2 \mathrm{G}$ ).

$\mathrm{H}_{2}$ usage started $11 \mathrm{~h}$ after inoculation, when the detected flow in the off-gas was $0.26 \pm 0.003 \mathrm{mmol} / \mathrm{min}(2.47 \pm 1.28 \%$ usage $)$. It stayed above $85 \%$ for $53.5 \mathrm{~h}$, from $21 \mathrm{~h}$ to $74.5 \mathrm{~h}$. The average usage during that time amounted to $93.75 \%$. The lowest flow of $\mathrm{H}_{2}$ detected in the off-gas was $0.006 \mathrm{mmol} / \mathrm{min}$ (97.64\% usage), between $39 \mathrm{~h}$ and $45 \mathrm{~h}$ (Figure 3G).

$\mathrm{CO}_{2}$ usage started after $20 \mathrm{~h}$, and lasted until $66 \mathrm{~h}$. The average usage was $10.31 \%$. Its maximum was $18.31 \pm 3.64 \%$, met at $41 \mathrm{~h}$ (Figure $2 \mathrm{G}$ ), when $0.13 \pm 0.01 \mathrm{mmol} / \mathrm{min}$ were detected in the off-gas (Figure 3G).

Between $21 \mathrm{~h}$ and $69 \mathrm{~h}$, maximum overall usage was detected (Table 4). For the complete run, the $\mathrm{E}_{\mathrm{C} \text {, total was }} 51.52 \pm 0.70 \mathrm{~mol} \%$ (Table 2 ).

As can be seen in Figure 2H, the syngas which emulated ENEA, used in set-up 8, presented a very similar profile regarding $\mathrm{CO}$ and $\mathrm{H}_{2}$ usage and $\mathrm{CO}$ fixation, but an increased $\mathrm{CO}_{2}$ usage: in fact, the highest of all gases tested. Maximum $\mathrm{CO}$ usage was achieved at $12 \mathrm{~h}$ of process-time, while maximum CO fixation happened just one hour later.

At $9 \mathrm{~h}$ of process-time, $\mathrm{H}_{2}$ usage slowly started, and passed the $85 \%$ usage mark at $17 \mathrm{~h}$, with $0.03 \pm 0.005 \mathrm{mmol} / \mathrm{min}$ in the off-gas (Figure $3 \mathrm{H}$ ). At $73 \mathrm{~h}$, maximum $\mathrm{H}_{2}$ usage stopped, and it kept decreasing until the end of the fermentation. During the interval of maximum usage, its average was $95.77 \%$, or $0.01 \mathrm{mmol} / \mathrm{min}$ detected in the waste gas stream.

$\mathrm{CO}_{2}$ usage was detected at $14 \mathrm{~h}$, very closely in time with the starting of maximum $\mathrm{CO}$ fixation. It reached its maximum, $37.08 \pm 4.07 \%$, which corresponds to $0.12 \pm 0.01 \mathrm{mmol} / \mathrm{min}$ in the off-gas (Figure $3 \mathrm{H}$ ), shortly after, at $18 \mathrm{~h}$. It lasted until $77.4 \mathrm{~h}$, with an average of $23 \%$, or $0.15 \mathrm{mmol} / \mathrm{min}$ in the off-gas.

The interval of maximum overall usage started five hours earlier than in set-up 7, at $16 \mathrm{~h}$,

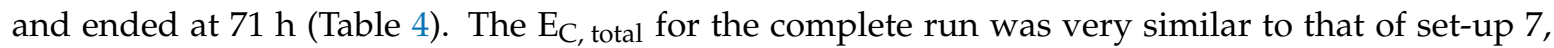
$50.88 \pm 1.71 \mathrm{~mol} \%$.

Biomass, Product Formation, Yield, and Productivity

Figure $4 \mathrm{G}$ shows the profiles for CDW and products throughout the fermentation for set-up 7 , while for set-up 8 this is depicted in Figure $4 \mathrm{H}$.

For the LNEG-like syngas, biomass increased up to $67 \mathrm{~h}$ of process-time, moment at which its maximum, $0.91 \pm 0.02 \mathrm{~g} / \mathrm{L}$ was measured. Afterwards, and until the end of the fermentation, it decreased continuously. Acetate formation started directly after inoculation, reaching $2.07 \pm 0.60 \mathrm{~g} / \mathrm{L}$ after $19 \mathrm{~h}$. At $74.5 \mathrm{~h}$, its concentration was $14.46 \pm 1.54 \mathrm{~g} / \mathrm{L}$, and from there on, the production slowed down. Its final concentration was $18.35 \pm 0.20 \mathrm{~g} / \mathrm{L}$. Up to $50 \mathrm{~h}$ of process-time, only $0.24 \pm 0.03 \mathrm{~g} / \mathrm{L} \mathrm{of}$ ethanol could be measured. From $67 \mathrm{~h}$, though, ethanol formation increased, reaching an end value of $1.91 \pm 0.13 \mathrm{~g} / \mathrm{L}$.

The end-point molar acetate to ethanol ratio was in this case $7.38 \pm 0.42$ (Table 2), while up to the point when maximum CO fixation stopped, it was $12.07 \pm 1.37$ (Table 3). The total productivities for both intervals were $0.21 \pm 0.001 \mathrm{~g} / \mathrm{L} \cdot \mathrm{h}$ (Table 2), and $0.23 \pm 0.01 \mathrm{~g} / \mathrm{L} \cdot \mathrm{h}$ (Table 3), respectively. Up to

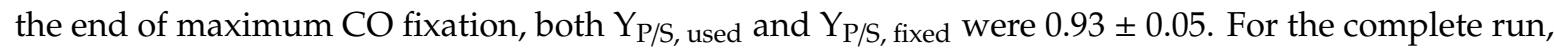
both yields were also similar among them, but lower than the ones obtained at the end, reflecting the slower product formation seen towards the end: $0.85 \pm 0.003 \mathrm{~g}_{\text {product }} / \mathrm{g}_{\text {substrate }}$ for $\mathrm{Y}_{\mathrm{P} / \mathrm{S} \text {, used }}$ and 
$0.88 \pm 0.02 \mathrm{~g}_{\text {product }} / \mathrm{g}_{\text {substrate }}$ for $\mathrm{Y}_{\mathrm{P} / \mathrm{S} \text {, fixed }}$. The amount of product per amount of biomass generated, $\mathrm{Y}_{\mathrm{P} / \mathrm{X}}$, at the end of the process was $29.29 \pm 0.51 \mathrm{~g}_{\text {product }} / \mathrm{g}_{\text {biomass }}$. Up to the end of maximum CO fixation, it was $21.34 \pm 1.98 \mathrm{~g}_{\text {product }} / \mathrm{g}_{\text {biomass }}$.

The fermentation with ENEA-based syngas, set-up 8, resulted in less biomass formation. During the first $26 \mathrm{~h}$, a faster growth was detected. At $50 \mathrm{~h}$, the measured biomass amounted to $0.80 \pm 0.06 \mathrm{~g} / \mathrm{L}$. Its maximum was detected at $72 \mathrm{~h}$, with $0.86 \pm 0.09 \mathrm{~g} / \mathrm{L}$. Afterwards, a decrease in the biomass concentration was observed, with a final concentration of $0.69 \pm 0.06 \mathrm{~g} / \mathrm{L}$. Even so, acetate and ethanol formation presented a very similar pattern to the previous fermentation, with $2.73 \pm 0.33 \mathrm{~g} / \mathrm{L}$ of acetate produced after $19 \mathrm{~h}$. It slowed down slightly after $69 \mathrm{~h}$, similarly to what is observed in set-up 8 , and coinciding with the halt in growth. Nonetheless, its concentration kept rising until the end of the process, when it reached $18.02 \pm 0.43 \mathrm{~g} / \mathrm{L}$. Ethanol production, much like set-up 7, was very low for the first $50 \mathrm{~h}$, with $0.24 \pm 0.04 \mathrm{~g} / \mathrm{L}$ detected at that time. Afterwards, its concentration in the fermenter raised, getting to its end value of $1.51 \pm 0.05 \mathrm{~g} / \mathrm{L}$, lower than in the previous run.

The obtained molar acetate to ethanol ratio at the end of the fermentation was, as expected due to the lower ethanol, somehow higher than for the previous set-up, $9.16 \pm 0.26$ (Table 1). This is also true for the value obtained up to the end of the maximum CO fixation, $14.89 \pm 1.99$ (Table 3). Productivities, both calculated at the end-point or up to the maximum CO fixation point, were slightly inferior for set-up 8 (Tables 2 and 4). The total, end-point productivity was $0.20 \pm 0.004 \mathrm{~g} / \mathrm{L} \cdot \mathrm{h}$. The yields obtained were also lower, especially when looking at the complete run. They were also very similar among them,

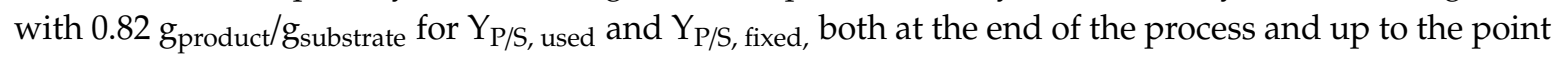
when maximum $C O$ fixation ended. Finally, the end-point $\mathrm{Y}_{\mathrm{P} / \mathrm{X}}$ resulted in $31.01 \pm 1.96 \mathrm{~g}$ product $/ \mathrm{g}_{\text {biomass }}$, very similar to that of set-up 7. As for the resulting $\mathrm{Y}_{\mathrm{P} / \mathrm{X}}$ calculated to the point of maximum $\mathrm{CO}$ fixation, it amounted to $21.73 \pm 0.58$ g product $/ g_{\text {biomass }}$, equivalent to that of set-up 7 .

\subsubsection{Custom Mixtures A and B, Set-Ups 9 and 10}

\section{Substrate Usage and Carbon Fixation}

As illustrated in Figure 2I, CO usage started following inoculation on set-up 9, with 85\% usage after $21 \mathrm{~h}$. It reached $97.61 \pm 0.31 \%$ five hours later, at $26 \mathrm{~h}$, and its maximum, $98.90 \pm 0.98 \%$ at $48 \mathrm{~h}$. Average CO usage only dropped below 85\% shortly before the end of the experiment, at $92 \mathrm{~h}$ of process-time, but the higher standard deviation shows some discrepancy between the individual bioreactors. Concerning CO fixation, it first reached its maximum at $28 \mathrm{~h}$, with $85.32 \pm 0.18 \%$, when $0.006 \pm 0.001 \mathrm{mmol} / \mathrm{min}$ (Figure 3I) were leaving the fermenter with the off-gas. Maximum CO fixation stopped at $59 \mathrm{~h}$ (Figure $2 \mathrm{I}$ and Table 4 ).

It took $19 \mathrm{~h}$ for $\mathrm{H}_{2}$ usage to rise above $3 \%$ : up to that point, it averaged $0.97 \%$. Afterwards, it increased rapidly, reaching $84.91 \pm 4.46 \%$ (Figure 2I), or $0.03 \pm 0.01 \mathrm{mmol} / \mathrm{min}$ in the off-gas (Figure 3I), at $27 \mathrm{~h}$. At $71 \mathrm{~h}$ it had decreased to $83.75 \pm 6.04 \%$, and it continued to sharply decline afterwards.

$\mathrm{No} \mathrm{CO}_{2}$ usage could be detected in this set-up 9 fermentation. At $19 \mathrm{~h}$, the amount of $\mathrm{CO}_{2}$ detected in the waste gas stream peaked at $0.18 \pm 0.01 \mathrm{mmol} / \mathrm{min}$ (Figure $3 \mathrm{I}$ ), which would be $-88.35 \pm 4.87 \%$ in terms of usage (or $88.35 \pm 4.87 \%$ production).

The period between $28 \mathrm{~h}$ and $66 \mathrm{~h}$ was that of maximum overall usage (Table 4 ). The resulting $\mathrm{E}_{\mathrm{C} \text {, total }}$ for this set-up at the end-point was determined to be $46.61 \pm 0.96 \mathrm{~mol} \%$ (Table 2).

Moving on to set-up 10, CO usage started, as well, directly after inoculation (Figure 2J). It surpassed $85 \%$ at $16.5 \mathrm{~h}$, with $85.92 \pm 11.12 \%$, and reached its higher value, $99.18 \pm 1.42 \%$ at $47 \mathrm{~h}$. From then on, and until the end of the fermentation, it remained at an average of $96.32 \%$, which means that an average of $0.008 \mathrm{mmol} / \mathrm{min}$ (Figure $4 \mathrm{~J}$ ) of CO was living the reactor. Looking at the CO fixation, it reached its maximum at $20 \mathrm{~h}$, with $87.40 \pm 10.59 \%$. At $75 \mathrm{~h}$, it dropped below $85 \%$ and continued to do so until the end-point. 
$\mathrm{H}_{2}$ usage averaged $1.82 \%$ during the first $13 \mathrm{~h}$, starting to increase from that point on to reach $86.68 \pm 5.95 \%$ at $23 \mathrm{~h}$. At $46 \mathrm{~h}$ its maximum was met, with $0.006 \pm 0.002 \mathrm{mmol} / \mathrm{min}$ in the off-gas (Figure 3J), and $97.14 \pm 1.01 \%$ usage (Figure $2 \mathrm{~J}$ ). At $71 \mathrm{~h}$, maximum usage stopped.

$\mathrm{CO}_{2}$ usage was first detected after $23 \mathrm{~h}$, coinciding with the moment when $\mathrm{H}_{2}$ usage reached its maximum, and lasted until $58 \mathrm{~h}$ of process-time. The average usage during this period was $6.93 \%$, with its maximum being $11.34 \pm 2.99 \%$ at $43 \mathrm{~h}$, or $0.125 \pm 0.005 \mathrm{mmol} / \mathrm{min}$ in the off-gas (Figure 3J).

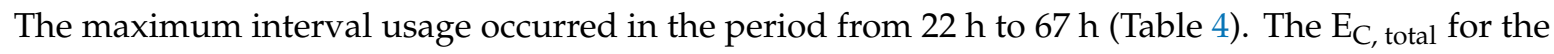
complete run for set-up 10 was $47.75 \pm 1.49 \mathrm{~mol} \%$ (Table 2 ).

Biomass, Product Formation, Yield, and Productivity

Products and biomass formation are shown in Figure 4I for set-up 9. As can be seen, biomass increased the fastest during the first $26.5 \mathrm{~h}$, when the measured concentration was $0.43 \pm 0.03 \mathrm{~g} / \mathrm{L}$. Later on, growth slowed down, reaching $0.65 \pm 0.06 \mathrm{~g} / \mathrm{L}$ at $50.5 \mathrm{~h}$ and finally its maximum, $0.69 \pm 0.01 \mathrm{~g} / \mathrm{L}$ at $67.5 \mathrm{~h}$. From that point on, biomass stagnated and eventually decreased.

At process-time $24 \mathrm{~h}, 2.17 \pm 0.34 \mathrm{~g} / \mathrm{L}$ of acetate was measured. From there on, the acetate concentration increased up to $43 \mathrm{~h}$, remaining constant thereafter. The final concentration measured was $16.28 \pm 1.09 \mathrm{~g} / \mathrm{L}$. The detected ethanol remained very low, and practically constant, with an average of $0.22 \mathrm{~g} / \mathrm{L}$ from $20 \mathrm{~h}$ to $50.5 \mathrm{~h}$. At $67.5 \mathrm{~h}$, an increase in its production was observed, reaching $0.41 \pm 0.05 \mathrm{~g} / \mathrm{L}$, totaling $1.05 \pm 0.07 \mathrm{~g} / \mathrm{L}$ at the end of the fermentation.

The final molar ratio of acetate to ethanol was $11.92 \pm 0.85$ (Table 2), while if calculated up to the point when maximum CO fixation ended, it was $45.20 \pm 7.39$, the highest value amongst all fermentations (Table 3).

The total productivity up to the end of maximum CO fixation was $0.19 \pm 0.002 \mathrm{~g} / \mathrm{L} \cdot \mathrm{h}$ (Table 3), and $0.18 \pm 0.01 \mathrm{~g} / \mathrm{L} \cdot \mathrm{h}$ (Table 2) for the complete run.

$\mathrm{Y}_{\mathrm{P} / \mathrm{S} \text {, used }}$ and $\mathrm{Y}_{\mathrm{P} / \mathrm{S} \text {, fixed }}$ were $0.72 \pm 0.04 \mathrm{~g}_{\text {product }} / \mathrm{g}_{\text {substrate }}$ and $0.91 \pm 0.04 \mathrm{~g}$ product $/ \mathrm{g}_{\text {substrate, }}$ respectively, for the entire run (Table 2). Up to the end of $\mathrm{CO}$ fixation, these were $0.83 \pm 0.01 \mathrm{~g}_{\text {product }} / \mathrm{g}_{\text {substrate }}$ for $\mathrm{Y}_{\mathrm{P} / \mathrm{S} \text {, used }}$ and $0.99 \pm 0.01 \mathrm{~g}_{\text {product }} / \mathrm{g}_{\text {substrate }}$ for $\mathrm{Y}_{\mathrm{P} / \mathrm{S} \text {, fixed }}$. The obtained end-point $\mathrm{Y}_{\mathrm{P} / \mathrm{X}}$ was $29.49 \pm 1.01 \mathrm{~g}_{\text {product }} / \mathrm{g}_{\text {biomass }}$ while up to the point when maximum $\mathrm{CO}$ fixation ended was almost half, $15.34 \pm 1.16$ g product $/ g_{\text {biomass }}$.

Figure $4 \mathrm{~J}$ shows growth and acetate and ethanol production of set-up 10 . In terms of growth, this fermentation followed a very similar pattern to that of set-up 9. Biomass increased at a faster rate for the first hours, reaching $0.48 \pm 0.02 \mathrm{~g} / \mathrm{L}$ after $26 \mathrm{~h}$, slowing down afterwards, and reaching $0.65 \pm 0.03 \mathrm{~g} / \mathrm{L}$ at $50 \mathrm{~h}$. At $67 \mathrm{~h}$, it had only increased slightly to $0.67 \pm 0.04 \mathrm{~g} / \mathrm{L}$, starting to decrease thereafter.

Acetate formation also followed an equivalent trend to that of the previous set-up, with a slower production for the first $19 \mathrm{~h}$, followed by a continuous production, reaching a final concentration of $15.65 \pm 0.89 \mathrm{~g} / \mathrm{L}$.

Ethanol formation started earlier in this case. At $50 \mathrm{~h} 0.38 \pm 0.06 \mathrm{~g} / \mathrm{L}$ were detected, increasing to $0.77 \pm 0.05 \mathrm{~g} / \mathrm{L}$, and finally $1.77 \pm 0.24 \mathrm{~g} / \mathrm{L}$ at the last sample taken, at $93.5 \mathrm{~h}$.

Regarding the productivity, taking into consideration the overall process, it was slightly higher to set-up $9,0.19 \pm 0.02 \mathrm{~g} / \mathrm{L} \cdot \mathrm{h}$. When calculated up to the point when maximum CO fixation ended, it was $0.20 \pm 0.01 \mathrm{~g} / \mathrm{L} \cdot \mathrm{h}$.

Finally, the yield at the end-point equaled to $0.87 \pm 0.07$ g product $/ \mathrm{g}_{\text {substrate }}$ for $\mathrm{Y}_{\mathrm{P} / \mathrm{S} \text {, used, }}$, while $\mathrm{Y}_{\mathrm{P} / \mathrm{S} \text {, fixed }}$ was $0.96 \pm 0.03 \mathrm{~g}_{\text {product }} / \mathrm{g}_{\text {substrate. }} \mathrm{Y}_{\mathrm{P} / \mathrm{X}}$ as calculated from the final sample, was $33.49 \pm 2.30 \mathrm{~g}_{\text {product }} / \mathrm{g}_{\text {biomass }}$ and the same parameter calculated up to the point of maximum $\mathrm{CO}$ fixation equaled $20.38 \pm 0.89$ g product $/ g_{\text {biomass }}$.

\subsubsection{Productivity and Product Ratio Comparison According to Syngas Type and Composition}

The results for the fermentation of biomass-derived TNO gas from beech wood and lignin were reported in Liakakou, Infantes et al. [31]. These are shown as stars $\left(^{*}\right)$ in Figure 4, Figure 5, Figure 6. 


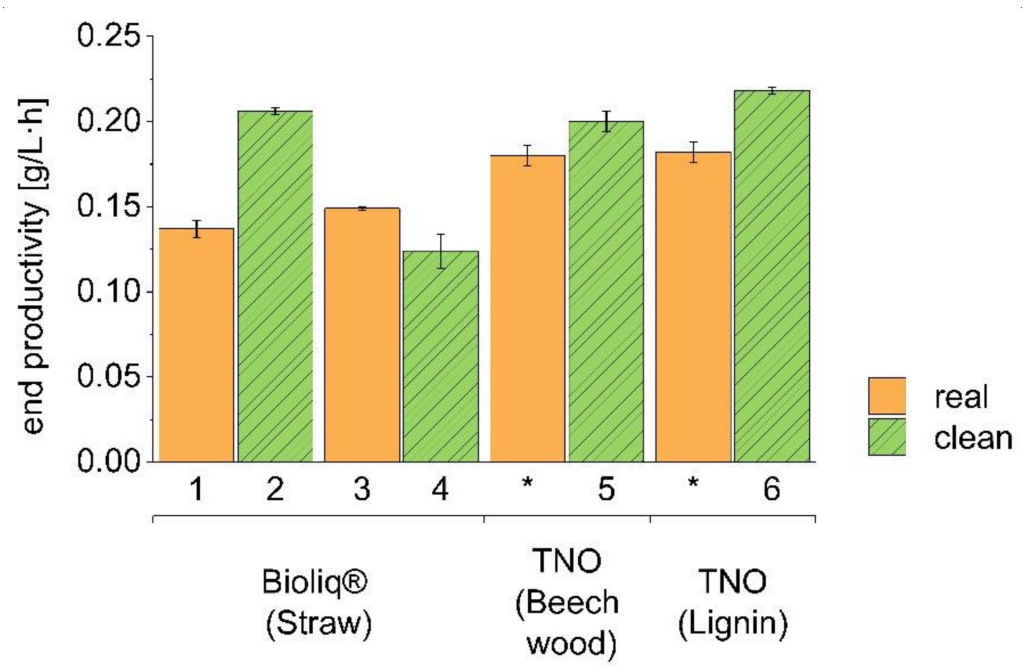

Figure 5. End-point productivity for pairs of real and clean syngases. Numbers 1 to 6 indicate the set-up, while stars $\left(^{*}\right)$ refer to TNO real gases (data published elsewhere, [31]). The productivity, as measured at the end of the fermentation, is shown by the bars. Real, biomass-derived syngases are represented by smooth orange bars, while clean, commercially-mixed syngases are shown by diagonally striped green bars. All values are given as the average of a triplicate, with standard deviation.

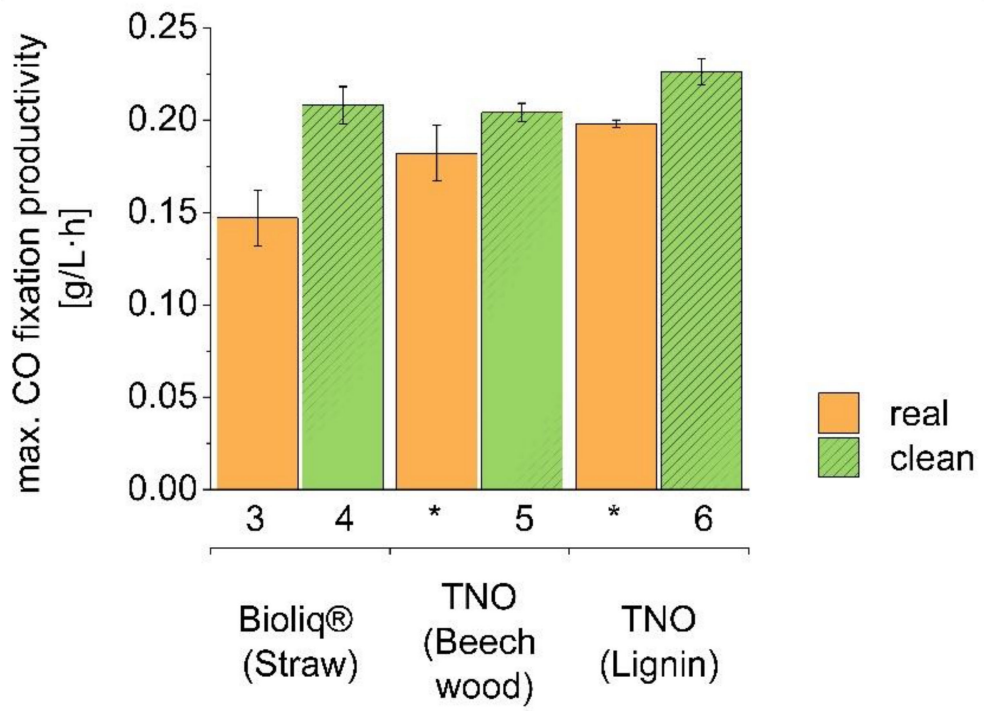

Figure 6. Productivity up to the end of maximum CO fixation for pairs of real and clean syngases. Numbers 3 to 6 indicate the set-up, while stars $\left({ }^{*}\right)$ refer to TNO real gases (data published elsewhere, [31]). The productivity, as measured at the end of the fermentation, is shown by the bars. Real, biomass-derived syngases are represented by smooth orange bars, while clean, commercially-mixed syngases are shown by diagonally striped green bars. All values are given as the average of a triplicate, with standard deviation. No values are given for set-ups 1 and 2 due to the fact that no maximum CO fixation occurred.

As can be seen in Figure 5, for each pair of real and clean syngas tested under the same conditions, and for which the flow of carbon-containing substrates $\left(C_{i n}\right)$ was $0.4 \mathrm{mmol} / \mathrm{min}$ (Table 1$)$, the end-point productivity of the gas devoid of impurities was higher in all cases. Set-ups 1 and 2 present the highest difference amongst the experiments. 
For set-ups 3 and 4 , where the gas flow was lower, with $\mathrm{C}_{\text {in }}$ fixed at $0.3 \mathrm{mmol} / \mathrm{min}$ and $\mathrm{H}_{2 \text {,in }}$ at $0.2 \mathrm{mmol} / \mathrm{min}$ (Table 1), the opposite is true: the biomass-derived syngas, containing impurities, presented a higher final productivity.

When the productivity is calculated up to the end of maximum $\mathrm{CO}$ fixation, the clean gases present a higher productivity in all cases (Figure 6). As mentioned above, set-ups 1 and 2 are not included due to the fact that no maximum CO fixation (no CO fixation above 85\%) was detected.

Figure 7 illustrates the molar ratio of acetate to ethanol for the pairs of experiments comparing clean and real syngases. It can be seen that, depending on whether the syngas is "real" (biomass-derived), or clean (that is, commercially mixed and free from impurities), the product profile changes. All clean gases produce a higher acetate to ethanol ratio, while their biomass-derived counterparts generate a greater amount of ethanol per mol of acetate.

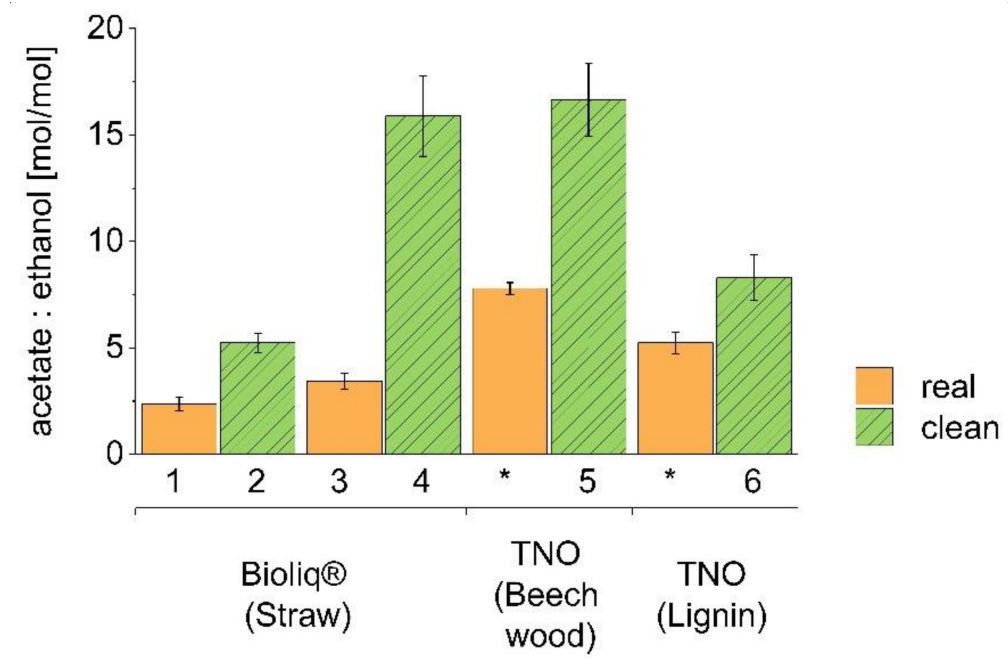

Figure 7. Molar acetate to ethanol ratio for pairs of real and clean syngases. Numbers 1 to 6 indicate the set-up, while stars $\left({ }^{*}\right)$ refer to TNO real gases (data published elsewhere, [31]). The ratio of acetate to ethanol, in mol, as measured at the end of the fermentation, is shown by the bars. Real, biomass-derived syngases are represented by smooth orange bars, while clean, commercially-mixed syngases are shown by diagonally striped green bars. All values are given as the average of a triplicate, with standard deviation.

A visual representation of the influence of the molar flow rate of each substance in the tested clean syngases on the product distribution is shown in Figure 8. From the eight set-ups which were performed with an impurity-free syngas, the ones with a lower $\mathrm{H}_{2} \mathrm{flow}, \leq 0.23 \mathrm{mmol} / \mathrm{min}$, appear to generate the highest acetate to ethanol ratio. There is one exception, set-up 10, which had the same $\mathrm{H}_{2}$ molar flow as set-up 4, $0.23 \mathrm{mmol} / \mathrm{min}$ (Table 1), but did result in a much lower acetate to ethanol ratio. The molar $\mathrm{CO}$ flow rate was also equivalent, $0.23 \mathrm{mmol} / \mathrm{min}$ for set-up 4 and $0.22 \mathrm{mmol} / \mathrm{min}$ for set-up 10. The main difference here was the molar $\mathrm{CO}_{2}$ flow, which in set-up 10 was 7 times higher $(0.14 \mathrm{mmol} / \mathrm{min})$ than in set-up 4 , with just $0.02 \mathrm{mmol} / \mathrm{min}$.

The mid-range of the acetate-ethanol ratio for the syngases here tested were obtained with the higher $\mathrm{CO}_{2}$ molar flow rate, $\geq 0.14 \mathrm{mmol} / \mathrm{min}$, and a molar flow rate of $\mathrm{H}_{2} \geq 0.22 \mathrm{mmol} / \mathrm{min}$.

The lower acetate to ethanol ratio, or the fermentation which produced a higher amount of ethanol per amount of acetate, was achieved by the syngas containing the highest $\mathrm{H}_{2}$ and $\mathrm{CO}$ molar flow, together with the lowest molar flow of $\mathrm{CO}_{2}$. 


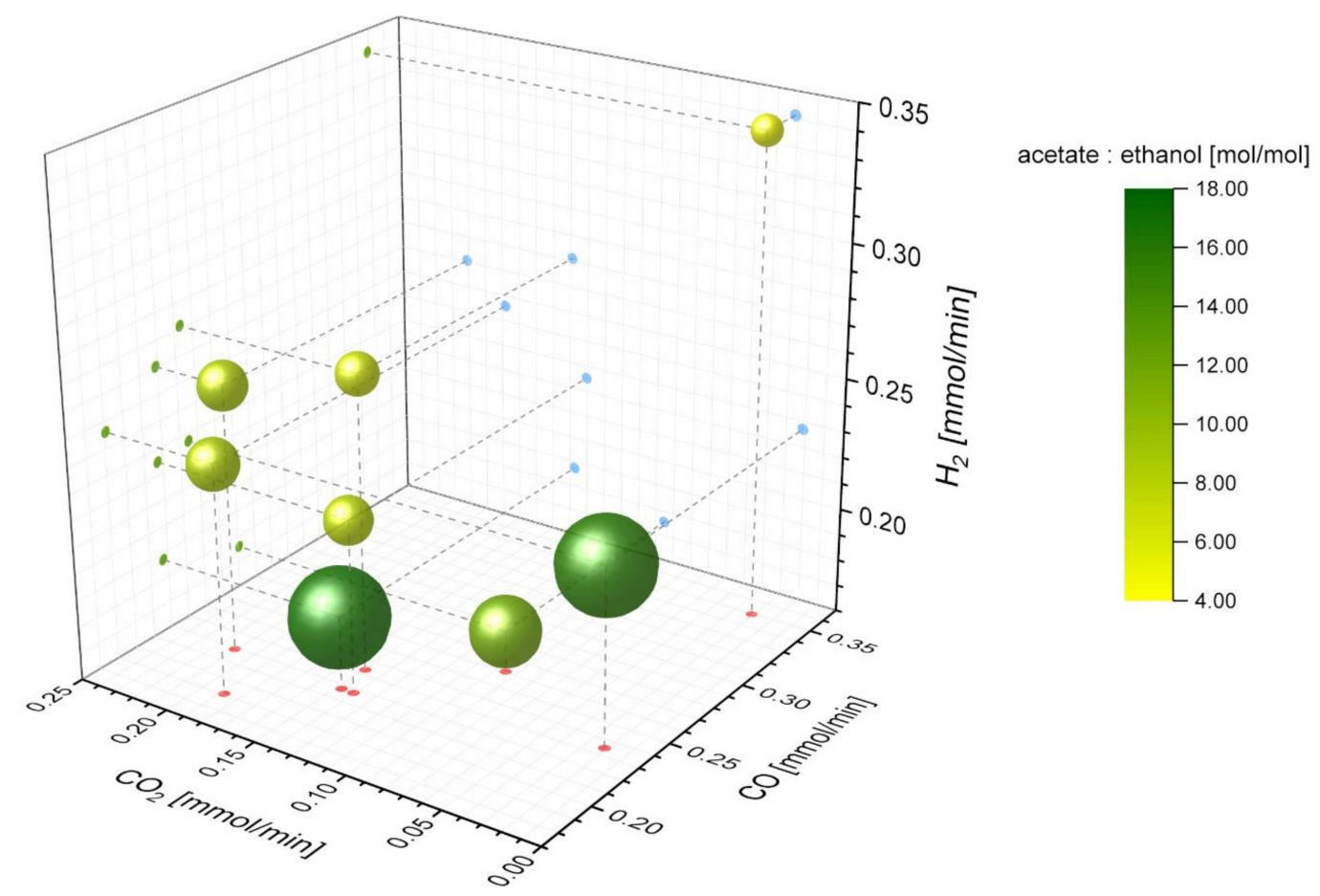

Figure 8. Molar acetate to ethanol ratio obtained from each combination of tested $\mathrm{CO}, \mathrm{CO}_{2}$, and $\mathrm{H}_{2}$ molar substrate flow rate for clean syngases. The acetate to ethanol molar ratio for set-ups 2,4 , and 5 to 10 is shown according to the molar flow rate of each substance fed into the bioreactor. The size and color of each bubble is proportional to the molar acetate to ethanol ratio. Smaller size and yellow color denote a lower acetate to ethanol ratio. Bigger bubbles and green color, indicates a higher acetate to ethanol ratio. $\mathrm{H}_{2}$ is represented on the $\mathrm{Z}$ axis, $\mathrm{CO}_{2}$ on the $\mathrm{Y}$ axis and $\mathrm{CO}$ on the $\mathrm{X}$ axis. Blue dots represent the $\mathrm{YZ}$ projection, red dots the $\mathrm{XY}$ projection, and green dots, the $\mathrm{ZX}$ projection. Drop lines (dotted grey lines) are visual aids to assigning each bubble its value in each axis.

\section{Discussion}

\subsection{Biomass, Product Formation, Yield and Productivity}

Theoretical yield and carbon fixation calculations have to be re-considered when dealing with biomass-derived syngas. The complexity of the impurities which are present in the gas mixture highlight the necessity of having a system where each biomass-derived syngas can be tested before its implementation in a continuous, bigger-scale system.

Besides, theoretical yields and ideal gas ratios only apply for resting cells, and it can be of interest to know how the gas composition affects the growing phase of the cells, to try and optimize this stage also: in one report it was stated that cells took up to 8 days for the OD to stabilize [25], and, in another study, it was reported that even with bottled, clean syngas, a lag phase of 4 days was observed [18].

Even if the same amount of total carbon, $0.4 \mathrm{~mol} / \mathrm{min}$, was fed in all set-ups (except for set-ups 3 and 4) the different $\mathrm{CO}: \mathrm{CO}_{2}: \mathrm{H}_{2}$ ratio of the syngases clearly had an influence. This was to be expected, as each component has a different solubility. Here, the precise impact of each syngas could be shown: gas composition had, in some cases, a marked effect in growth, but not so significant in product formation, especially up to the first half of the run. Except for set-up 4, all other clean gases achieved a concentration of acetate of approximately $10 \mathrm{~g} / \mathrm{L}$ at around $50 \mathrm{~h}$, but this changed towards the second half of the fermentation: the product ratio and its concentration were strongly affected by the syngas composition, as shown in Figure 8.

In terms of growth, all biomass-derived syngases tested could successfully be used as a fermentation substrate, offering proof that the level of clean-up of the syngases is enough for syngas fermentation. 
This is a critical point when assessing biomass-derived syngas: cells have been reported to stop growing when biomass-derived syngas was supplied [18]. As well, Ahmed et al. [25] observed that cells stopped growing when a $0.2 \mu \mathrm{m}$ filter was applied on the biomass-derived syngas inlet, but this was reversed when it was replaced by a $0.025 \mu \mathrm{m}$ filter.

When comparing each pair of clean and biomass-derived syngases, end productivities were generally not greatly affected, even if a better performance was achieved in most cases with clean syngas. The increased production of a more valuable product, ethanol, when biomass-derived syngas was used, could counteract the lower productivity up to an extent, depending on the down-stream processing requirements and the market value of the products. In case of set-up 4, the obtained yield for $\mathrm{Y}_{\mathrm{P} / \mathrm{S} \text {,fixed }}$ calculated up to the end of maximum CO fixation was slightly above $1\left(1.03 \pm 0.04 \mathrm{~g}_{\text {product }} / \mathrm{g}_{\text {substrate }}\right)$; this is regarded as the result of small analytical inexactitudes and should be interpreted as being close to 1.

Focusing on set-up 3 and 4 , the total productivity at the end of the fermentation of the biomass-derived syngas (set-up 3) was higher than what was obtained with clean syngas (set-up 4), despite the acetate productivity of both runs being equivalent. As happened for set-ups 1 and 2, the ethanol productivity was higher in the set-up using biomass-derived syngas. For the values obtained up to the end of maximum CO fixation, the opposite is true for total and acetate productivity: set-up 4 has higher values in this case. This difference can be explained because gas consumption ended much earlier in set-up 4: in the calculation for the end of process values, a long time span where the culture was not active is included, lowering the resulting productivity values.

\subsection{Substrate Usage and Carbon Fixation}

The gas composition had a big role in how long the maximum CO fixation lasted, as well as the presence of impurities in the syngas. In all cases, clean, impurity-free syngases showed a prolonged $\mathrm{CO}$ fixation when compared to their biomass-derived counterpart.

Another question encountered is whether simultaneous consumption of $\mathrm{H}_{2}$ and $\mathrm{CO}$ can be achieved for a given syngas composition-the inhibition kinetics of $\mathrm{H}_{2}$ or $\mathrm{CO}$ in acetogens are not well understood so far [12] — and what influence the impurities in biomass-derived syngas will have. Here, $\mathrm{H}_{2}$ usage was observed in all biomass-derived gases, albeit each of the respective clean syngas presented a higher consumption of $\mathrm{H}_{2}$, except, as already explained, set-ups 3 and 4 , the Bioliq ${ }^{\circledR}$ syngas fermentations at a lower gas flow. The successful $\mathrm{H}_{2}$ usage is a very positive outcome for the further usage, and optimization, of the biomass-derived syngases here tested. This point is not trivial: according to Esquivel-Elizondo et al. [36], not many studies observe concomitant $\mathrm{H}_{2}$ and $\mathrm{CO}$ usage, and keeping an optimal ratio of the syngas components is key for the sustainability of the process. In some cases, biomass-derived syngas has been shown to cause $\mathrm{H}_{2}$ consumption to stop [25], while in a study with Clostridium carboxidivorans $\mathrm{P} 11$, it was concluded that, at $\mathrm{H}_{2}$ partial pressures normally occurring in biomass-derived syngas, the hydrogenase efficiency would not be at its optimum [37].

The simultaneous consumption of $\mathrm{H}_{2}$ and $\mathrm{CO}$ started, in all cases, after the $\mathrm{CO}$ consumption had increased, but in some cases, before it reached complete consumption. Due to the increasing biomass concentration, the amount of dissolved $\mathrm{CO}$ in the medium decreases, enabling $\mathrm{H}_{2}$ uptake $[38,39]$. This can also explain why growth and $\mathrm{H}_{2}$ usage were linked in all cases: when growth stopped, so did $\mathrm{H}_{2}$ usage. As fewer cells are metabolically active, there is less competence for $\mathrm{CO}$, and each remaining active cell is exposed to a higher $\mathrm{CO}$ concentration, leading to a decline in $\mathrm{H}_{2}$ consumption. This observation agrees with what has been reported by Valgepea et al. [40], and it could be confirmed that it is valid for both, clean, and biomass-derived syngas, as long as no hydrogenase-inhibiting compound is present.

Regarding total carbon fixation $\left(\mathrm{E}_{\mathrm{C}, \text { total }}\right)$, it can be clearly seen that, for the same syngas composition, this was negatively impacted by impurities in biomass-derived syngas. Predicting up to which extent, is, nowadays, not possible, and it would need to be empirically determined by testing each biomass-derived syngas in a fermentation system to assess its impact. 


\subsection{Product Ratio Comparison According to the Type and Composition of Syngas}

The complexity of the factors being involved in the outcome of different $\mathrm{CO} / \mathrm{CO}_{2} / \mathrm{H}_{2}$ syngas mixtures is evident, and the obtained product ratios are not always in accordance with what is observed when gas mixtures consisting of only two components are used $\left(\mathrm{CO} / \mathrm{CO}_{2}, \mathrm{H}_{2} / \mathrm{CO}_{2}, \mathrm{CO} / \mathrm{H}_{2}\right)$. There are several reports on the effect of, mostly, only pairs of these syngas constituents, however, the combined effect of $\mathrm{CO} / \mathrm{CO}_{2} / \mathrm{H}_{2}$ blends have not been widely considered.

Looking at the different clean, impurity-free syngases tested here, it can be seen that higher $\mathrm{H}_{2}$ together with very low amounts of $\mathrm{CO}_{2}$ directs the cell metabolism towards the production of ethanol: the highest $\mathrm{H}_{2}$ and $\mathrm{CO}$, with very low $\mathrm{CO}_{2}$, produced the highest ethanol (Figure 8). This outcome agrees with what was reported by Valgepea et al. [39]: if $\mathrm{CO}$ was supplied together with $\mathrm{H}_{2}, \mathrm{more}$ ethanol was produced. Similar results were also documented by Hurst and Lewis [41], which used a system fed with $\mathrm{CO}_{2}$ and $\mathrm{CO}$. Different $\mathrm{CO}$ partial pressures were tested, and at higher $\mathrm{P}_{\mathrm{CO}}$, ethanol increased. They postulated that, when cells stop growing, less ATP is needed, and the excess electrons generated by the higher $\mathrm{P}_{\mathrm{CO}}$ can be directed towards ethanol.

Moreover, the data presented here show that when $\mathrm{CO}_{2}$ is supplied in higher amounts, $\mathrm{H}_{2}$ does not seem to have such a significant impact, but if analyzing the runs with a similar $\mathrm{CO}$ gas flow rate (between 0.20 and $0.25 \mathrm{mmol} / \mathrm{min}$ ), the highest acetate to ethanol ratios were obtained with lower $\mathrm{H}_{2}$ and $\mathrm{CO}_{2}$ (Figure 8). Looking at the findings by Phillips et al. [42], it could be concluded that $\mathrm{H}_{2}$ does not contribute towards the product shift to ethanol, contrary to what is found here. In that report, when comparing two gas mixtures, $\mathrm{H}_{2} / \mathrm{CO}_{2}$ and $\mathrm{CO} / \mathrm{CO}_{2}$, the one containing $\mathrm{CO}$ resulted more favorable for growth and ethanol production. It is important to note, though, that those experiments where performed in bottles, in batch, where the gas was dispensed into the head-space without a continuous supply. In yet another set of batch experiment, different mixtures of $\mathrm{H}_{2} / \mathrm{CO}$ were investigated. Acetate formation increased with increasing $\mathrm{H}_{2}$ concentrations in the headspace of the serum bottles, and more ethanol was produced when the CO concentration increased. [43]. These findings could also lead to assuming that lower $\mathrm{H}_{2}$ would cause the product ratio to shift towards ethanol, contrarily to what has been shown here and in a study by Esquivel-Elizondo et al. [36]. There, both $\mathrm{CO}$ alone and $\mathrm{CO} / \mathrm{H}_{2}$ produced more ethanol than $\mathrm{CO} / \mathrm{CO}_{2}$ and $\mathrm{CO} / \mathrm{CO}_{2} / \mathrm{H}_{2}$ mixtures. Yet, concluding that lower $\mathrm{CO}_{2}$ equals, in all cases, higher ethanol production would not be accurate, as already discussed above. Syngas mixtures, composed of varying amounts of $\mathrm{H}_{2} / \mathrm{CO}_{2} / \mathrm{CO}$, present a much more complex challenge, due to the combined effect of each component upon the others. A much more thorough study would need to be conducted, in order to better understand this, and potentially predict the outcome of different syngases.

Comparing clean and real biomass-derived syngas, the scenario changes drastically: gas composition did not play the biggest role in terms of product distribution; rather, the nature of the syngas did. All biomass-derived syngases produced a higher ethanol to acetate molar ratio, without a direct correlation to their composition. A metabolic regulatory mechanism has been postulated for Clostridium autoethanogenum, an organism which is closely related to C. ljungdahlii [44]. In that study, Valgepea et al. [40] reported that the increased acetic acid concentration in the medium, with the subsequent proton translocation into the cell, causes an uncoupling of the proton motive force (PMF). At higher biomass and acetate concentrations, cells try to gain more ATP by forming acetate, which causes the depletion of the acetyl-CoA pool due to the WLP not being able to function quickly enough. Eventually, this causes a metabolic crash, where the ability to uptake $\mathrm{H}_{2}$ is lost while the cells try to counteract the PMF uncoupling. The subsequent result is that more $\mathrm{CO}$ is oxidized to $\mathrm{CO}_{2}$ to try and maintain the amounts of reduced ferredoxin. Since less carbon is available for the WLP, the metabolism will eventually collapse. To counteract this, cells shift towards ethanol production in order to prevent the further uncoupling of the PMF, and still be able to conserve energy [40]. A similar mechanism could potentially also explain the behavior when other stress factors are present, like impurities in the syngas. Rather than the increased acetic acid concentration, the inhibitory effect of the impurities on the WLP enzymes could also cause a slowdown of this pathway. This would have 
the same outcome, that is, a depleted acetyl-CoA pool, and less ATP formation. The ATP-maintenance mechanism would then come into action, even at lower acetate concentrations in the broth, increasing the ethanol production. This would prevent the early crash of the culture under the more challenging conditions caused by the biomass-derived syngas.

When comparing set-ups 1 to 4 , it can be observed that lowering the gas flow rate had some opposite effects on biomass-derived and clean syngas. Set-up 1 and 3 (where biomass-derived syngas was used) show much more similarities than set-ups 2 and 4 (impurity-free syngas). Comparing set-up 1 to set-up 3 , the lowering of the gas flow resulted in a higher CDW and acetate concentration in set-up 3 , and a slightly reduced ethanol production. One explanation for this could be that in set-up 3, due to the lower gas flow, fewer impurities were introduced in the medium compared to set-up 1. Possibly, due to the impurities in the syngas, the cells in set-up 1 were already limited and could not use the excess substrate being supplied with the higher flow, as the gas usage and fixation graphs show.

In contrast, when looking at set-ups 2 and 4 , a lower gas flow rate proved to be detrimental, with a sharp decrease in gas usage as well as CDW concentration after $55 \mathrm{~h}$, and a lower final product concentration, with only traces of ethanol being produced. In set-up 2, when cells reached a CDW of $0.7 \mathrm{~g} / \mathrm{L}$, the acetate concentration was still below $10 \mathrm{~g} / \mathrm{L}$. In set-up 4 , at the same CDW, the acetate concentration was already $10 \mathrm{~g} / \mathrm{L}$. As explained above, the crash seen in set-up 4 would agree to the fact that, for the same syngas composition, at the same CDW, but with higher acetate, the ATP needs cannot be met, and the culture crashes. The reason as to why ethanol was produced in set-up 2 but not in set-up 4 cannot be exclusively caused by the acetate concentration, as proposed by Richter et al. [45], since acetate production was higher in set-up 4 than in set-up 2. In this case, the reason behind appears to be the $\mathrm{H}_{2}$ amount fed. The consumption of $\mathrm{H}_{2}$ also has the effect of driving protons into the cell without ATP production [40], which, again, would cause the ATP maintenance system to come into action in set-up 2. This agrees with the increase in $\mathrm{CO}_{2}$ production observed. Moreover, in a follow-up study, the same group reported that $\mathrm{H}_{2}$ directed the metabolism towards an increased ethanol production [39].

Looking at set-ups 3 and 4, apart from the already discussed higher ethanol, a higher CDW was achieved in the former. This observation would support the ATP maintenance mechanism coming into action in response to the impurities: due to the shift in the product ratio, resulting in a lower acetate concentration and higher ethanol production, cells were able to prevent the crash, conserve energy and generate ATP, even if impurities were present. Nonetheless, this does not imply that impurities are beneficial, since the clean, impurity-free syngas achieved a higher $\mathrm{E}_{\mathrm{C} \text {,total }}$ as well as a higher total productivity up to the point of maximum $\mathrm{CO}$ fixation. The perceived better performance of set-up 3 when considering the whole run is caused by the early crash of set-up 4 after approximately $50 \mathrm{~h}$.

\section{Conclusions}

In this work, it could be seen that gas composition affected mainly growth. For clean syngases, product formation profiles during the first half of the fermentation were not much influenced by the gas composition. The second half of the process, though, was strongly affected by the syngas composition. With clean syngas, high $\mathrm{H}_{2}$ and low $\mathrm{CO}_{2}$ shifts the product formation towards more ethanol. When comparing clean and biomass-derived syngas, though, this is no longer true: the biggest influence was caused by the nature of the syngas, rather than by its composition.

Regarding gas consumption, it stopped earlier in biomass-derived syngases. As well, carbon fixation was negatively impacted by the biomass-derived syngas impurities.

Looking at each pair of clean and biomass-derived syngases compared here, the former achieved, in general, a better performance, in terms of productivity, than their biomass-derived counterparts. This could be counterbalanced, to an extent, by the increased production of the more valuable ethanol.

It is evident that a number of interacting factors, including metabolic regulatory mechanisms, gas solubility and mass transfer effects all can play a role when dealing with syngas mixtures of $\mathrm{CO} / \mathrm{CO}_{2} / \mathrm{H}_{2}$, and the extrapolation of results from one gas mixture to another is not guaranteed to 
successfully predicting the behavior of the cells. The same syngas composition, but with different gas flows, led to opposite results for the Bioliq ${ }^{\circledR}$ syngas, showcasing how important it is to be aware of the complexity of the synergistic effects involved.

Productivities and overall yields were higher when clean syngas was used, but this cannot be seen as a realistic scenario, especially considering the cost of syngas cleaning processes. Studies performed with impurity-free syngas are necessary and valuable, but it is of great importance for the advance of the syngas fermentation platform to further investigate the effect of biomass-derived syngas, if results are to be applicable in real case scenarios.

Supplementary Materials: The following are available online at http://www.mdpi.com/2311-5637/6/3/84/s1, Figure S1: Complete substrate usage and fixation for set-ups 1 to 4 . Table S1: Fermentation outcomes, yields, and productivities for the complete run with standard deviations, Table S2: Fermentation outcomes, yields, and productivities calculated up to the point when maximum $\mathrm{CO}$ fixation stopped, with standard deviations.

Author Contributions: Conceptualization, A.I.; methodology, A.I. and M.K.; software, A.I. and M.K.; validation, A.I., M.K. and A.N.; formal analysis, A.I.; investigation, A.I. and M.K.; resources, K.R. and A.N.; writing-Original draft preparation, A.I.; writing-Review and editing, M.K., K.R. and A.N.; visualization, A.I.; supervision, A.N.; project administration, A.N.; funding acquisition, A.N. All authors have read and agreed to the published version of the manuscript.

Funding: AI was supported by the German Federal Ministry of Education and Research and the Helmholtz Association of German Research Centers. Part of this work was done within the framework of Ambition Project, an ECRIA project funded by the European Union's Horizon 2020 research and innovation program, under grant agreement No. 731263 .

Acknowledgments: The authors acknowledge support by the Deutsche Forschungsgemeinschaft and the KIT-Publication Fund of the Karlsruhe Institute of Technology. We acknowledge the work by Laura Herrmann, who conducted her Bachelor thesis under the supervision of M.K., Ana B. Torres Martínez, who conducted her Bachelor thesis under the supervision of A.I., and Karoline Haack, who conducted an internship under the supervision of A.I. and M.K.

Conflicts of Interest: The authors declare no conflict of interest.

\section{References}

1. Edenhofer, O.; Pichs-Madruga, R.; Sokona, Y.; Kadner, S.; Minx, J.C.; Brunner, S.; Agrawala, S.; Baiocchi, G.; Bashamakov, I.A.; Blanco, G.; et al. Technical Summary. In Climate Change 2014: Mitigation of Climate Change. Contribution of Working Group III to the Fifth Assessment Report of the Intergovernmental Panel on Climate Change; Edenhofer, O., Pichs-Madruga, R., Sokona, Y., Farahani, E., Kadner, S., Seyboth, K., Adler, A., Baum, I., Brunner, S., Eickemeier, P., et al., Eds.; Cambridge University Press: Cambridge, UK; New York, NY, USA, 2014. [CrossRef]

2. McGlade, C.; Ekins, P. The geographical distribution of fossil fuels unused when limiting global warming to $2{ }^{\circ} \mathrm{C}$. Nature 2015, 517, 187-190. [CrossRef] [PubMed]

3. Friedlingstein, P.; Andrew, R.M.; Rogelj, J.; Peters, G.G.; Canadell, J.G.; Knutti, R.; Luderer, G.; Raupach, M.R.; Schaeffer, M.; Van Vuuren, D.P.; et al. Persistent growth of $\mathrm{CO}_{2}$ emissions and implications for reaching climate targets. Nat. Geosci. 2014, 7, 709-715. [CrossRef]

4. Henrich, E.; Dahmen, N.; Dinjus, E.; Sauer, J. The Role of Biomass in a Future World without Fossil Fuels. Chem. Ing. Tech. 2015, 87, 1667-1685. [CrossRef]

5. Sikarwar, V.S.; Zhao, M.; Clough, P.T.; Yao, J.; Zhong, X.; Memon, M.Z.; Shah, N.; Anthony, E.; Fennell, P. An overview of advances in biomass gasification. Energy Environ. Sci. 2016, 9, 2939-2977. [CrossRef]

6. Drake, H.L.; Küsel, K.; Matthies, C. Acetogenic prokaryotes. In The Prokaryotes, Vol. 2 (Ecophysiology and Biochemistry); Dworkin, M., Falkow, S., Rosenberg, E., Schleifer, K.-H., Stackebrandt, E., Eds.; Springer: New York, NY, USA, 2006; pp. 354-420. ISBN 978-0-387-30742-8. [CrossRef]

7. Bengelsdorf, F.R.; Beck, M.H.; Erz, C.; Hoffmeister, S.; Karl, M.M.; Riegler, P.; Wirth, S.; Poehlein, A.; Weuster-Botz, D.; Dürre, P. Bacterial Anaerobic Synthesis Gas (Syngas) and $\mathrm{CO}_{2}+\mathrm{H}_{2}$ Fermentation. In Advances in Applied Microbiology; Sariaslani, S., Gadd, G.M., Eds.; Academic Press: Cambridge, MA, USA, 2018; pp. 143-221. ISBN 978-0-12-815183-9. [CrossRef]

8. Sun, X.; Atiyeh, H.; Huhnke, R.L.; Tanner, R.S. Syngas fermentation process development for production of biofuels and chemicals: A review. Bioresour. Technol. Rep. 2019, 7, 100279. [CrossRef] 
9. LanzaTech World's First Commercial Waste Gas to Ethanol Plant Starts Up |LanzaTech. Available online: https: //www.lanzatech.com/2018/06/08/worlds-first-commercial-waste-gas-ethanol-plant-starts/ (accessed on 27 February 2020).

10. Griffin, D.W.; Schultz, M.A. Fuel and chemical products from biomass syngas: A comparison of gas fermentation to thermochemical conversion routes. Environ. Prog. Sustain. Energy 2012, 31, $219-224$. [CrossRef]

11. Munasinghe, P.C.; Khanal, S.K. Biomass-derived Syngas Fermentation into Biofuels. In Biofuels; Academic Press: Cambridge, MA, USA, 2011; pp. 79-98. [CrossRef]

12. Takors, R.; Kopf, M.; Mampel, J.; Bluemke, W.; Blombach, B.; Eikmanns, B.; Bengelsdorf, F.R.; Weuster-Botz, D.; Dürre, P. Using gas mixtures of $\mathrm{CO}, \mathrm{CO}_{2}$ and $\mathrm{H}_{2}$ as microbial substrates: The do's and don'ts of successful technology transfer from laboratory to production scale. Microb. Biotechnol. 2018, 11, 606-625. [CrossRef]

13. Liakakou, E.; Vreugdenhil, B.; Cerone, N.; Zimbardi, F.; Pinto, F.; André, R.; Marques, P.; Mata, R.; Girio, F. Gasification of lignin-rich residues for the production of biofuels via syngas fermentation: Comparison of gasification technologies. Fuel 2019, 251, 580-592. [CrossRef]

14. Yasin, M.; Cha, M.; Chang, I.S.; Atiyeh, H.K.; Munasinghe, P.; Khanal, S.K. Syngas Fermentation Into Biofuels and Biochemicals. In Biofuels: Alternative Feedstocks and Conversion Processes for the Production of Liquid and Gaseous Biofuels; Pandey, A., Larroche, C., Dussap, C.-G., Gnansounou, E., Khanal, S.K., Ricke, S., Eds.; Academic Press: Cambridge, MA, USA, 2019; pp. 301-327. ISBN 9780128168561. [CrossRef]

15. Cardarelli, F. Gases. In Materials Handbook; Springer London: London, UK, 2008; pp. $1037-1101$. ISBN 978-1-84628-669-8. [CrossRef]

16. Teixeira, L.V.; Moutinho, L.F.; Romão-Dumaresq, A.S. Gas fermentation of C1 feedstocks: Commercialization status and future prospects. Biofuels Bioprod. Biorefin. 2018, 12, 1103-1117. [CrossRef]

17. Min, F.; Dennis, S.; Kopke, M. Gas Fermentation for Commercial Biofuels Production. In Liquid, Gaseous and Solid Biofuels Conversion Techniques; Fang, Z., Ed.; IntechOpen: London, UK, 2013; pp. 125-173. [CrossRef]

18. Datar, R.P.; Shenkman, R.M.; Cateni, B.G.; Huhnke, R.L.; Lewis, R.S. Fermentation of biomass-generated producer gas to ethanol. Biotechnol. Bioeng. 2004, 86, 587-594. [CrossRef]

19. Bengelsdorf, F.R.; Straub, M.; Dürre, P. Bacterial synthesis gas (syngas) fermentation. Environ. Technol. 2013, 34, 1639-1651. [CrossRef] [PubMed]

20. Acharya, B.; Roy, P.; Dutta, A. Review of syngas fermentation processes for bioethanol. Biofuels 2014, 5, 551-564. [CrossRef]

21. Ramachandriya, K.D.; Kundiyana, D.K.; Sharma, A.M.; Kumar, A.; Atiyeh, H.; Huhnke, R.L.; Wilkins, M.R. Critical factors affecting the integration of biomass gasification and syngas fermentation technology. AIMS Environ. Sci. 2016, 3, 188-210. [CrossRef]

22. Ahmed, A.; Lewis, R.S. Fermentation of biomass-generated synthesis gas: Effects of nitric oxide. Biotechnol. Bioeng. 2007, 97, 1080-1086. [CrossRef] [PubMed]

23. $\mathrm{Xu}, \mathrm{D}$; Lewis, R.S. Syngas fermentation to biofuels: Effects of ammonia impurity in raw syngas on hydrogenase activity. Biomass Bioenergy 2012, 45, 303-310. [CrossRef]

24. Oswald, F.; Zwick, M.; Omar, O.; Hotz, E.N.; Neumann, A. Growth and Product Formation of Clostridium ljungdahlii in Presence of Cyanide. Front. Microbiol. 2018, 9. [CrossRef]

25. Ahmed, A.; Cateni, B.G.; Huhnke, R.L.; Lewis, R.S. Effects of biomass-generated producer gas constituents on cell growth, product distribution and hydrogenase activity of Clostridium carboxidivorans P7T. Biomass Bioenergy 2006, 30, 665-672. [CrossRef]

26. Xu, D.; Tree, D.R.; Lewis, R.S. The effects of syngas impurities on syngas fermentation to liquid fuels. Biomass Bioenergy 2011, 35, 2690-2696. [CrossRef]

27. Chiche, D.; Diverchy, C.; Lucquin, A.-C.; Porcheron, F.; Defoort, F. Synthesis Gas Purification. Oil Gas Sci. Technol. Rev. de l'IFP Energies Nouv. 2013, 68, 707-723. [CrossRef]

28. Tanner, R.S. Cultivation of Bacteria and Fungi. In Manual of Environmental Microbiology, 3rd ed.; Hurst, C., Crawford, R., Garland, J., Lipson, D., Mills, A., Stetzenbach, L., Eds.; ASM Press: Washington, DC, USA, 2007; pp. 69-78. [CrossRef]

29. Infantes, A.; Kugel, M.; Neumann, A. Evaluation of Media Components and Process Parameters in a Sensitive and Robust Fed-Batch Syngas Fermentation System with Clostridium ljungdahlii. Fermentation 2020, 6, 61. [CrossRef] 
30. Dahmen, N.; Abeln, J.; Eberhard, M.; Kolb, T.; Leibold, H.; Sauer, J.; Stapf, D.; Zimmerlin, B. The bioliq process for producing synthetic transportation fuels. Wiley Interdiscip. Rev. Energy Environ. 2017, 6, e236. [CrossRef]

31. Liakakou, E.T.; Infantes, A.; Neumann, A.; Vreugdenhil, B.J. Connecting lignin gasification with syngas fermentation (PREPRINT). engrXiv 2020. [CrossRef]

32. Cerone, N.; Zimbardi, F.; Contuzzi, L.; Prestipino, M.; Carnevale, M.O.; Valerio, V. Air-steam and oxy-steam gasification of hydrolytic residues from biorefinery. Fuel Process. Technol. 2017, 167, 451-461. [CrossRef]

33. Pinto, F.; André, R.; Marques, P.; Mata, R.; Pacheco, M.; Moura, P.; Gírio, F. Production of syngas suitable to be used in fermentation to obtain biochemical added-value compounds. Chem. Eng. Trans. 2019, 76, 1399-1404.

34. Oswald, F.; Dörsam, S.; Veith, N.; Zwick, M.; Neumann, A.; Ochsenreither, K.; Syldatk, C. Sequential Mixed Cultures: From Syngas to Malic Acid. Front. Microbiol. 2016, 7, 1-12. [CrossRef] [PubMed]

35. Oswald, F. Upgrading the Toolbox for Fermentation of Crude syngas: Process Characterization for Complete Carbon Usage, Cyanide Adaption and Production of C4 Components. Ph.D. Thesis, Karlsruhe Institute for Technology, Karlsruhe, Germany, 2018.

36. Esquivel-Elizondo, S.; Delgado, A.G.; Rittmann, B.E.; Krajmalnik-Brown, R. The effects of $\mathrm{CO}_{2}$ and $\mathrm{H}_{2}$ on CO metabolism by pure and mixed microbial cultures. Biotechnol. Biofuels 2017, 10, 220. [CrossRef]

37. Skidmore, B.E.; Baker, R.A.; Banjade, D.R.; Bray, J.M.; Tree, D.R.; Lewis, R.S. Syngas fermentation to biofuels: Effects of hydrogen partial pressure on hydrogenase efficiency. Biomass Bioenergy 2013, 55, 156-162. [CrossRef]

38. Bertsch, J.; Müller, V. Bioenergetic constraints for conversion of syngas to biofuels in acetogenic bacteria. Biotechnol. Biofuels 2015, 8,1-12. [CrossRef]

39. Valgepea, K.; Lemgruber, R.D.S.P.; Abdalla, T.; Binos, S.; Takemori, N.; Takemori, A.; Tanaka, Y.; Tappel, R.; Köpke, M.; Simpson, S.D.; et al. $\mathrm{H}_{2}$ drives metabolic rearrangements in gas-fermenting Clostridium autoethanogenum. Biotechnol. Biofuels 2018, 11, 1-15. [CrossRef]

40. Valgepea, K.; Lemgruber, R.D.S.P.; Meaghan, K.; Palfreyman, R.W.; Abdalla, T.; Heijstra, B.D.; Behrendorff, J.; Tappel, R.; Köpke, M.; Simpson, S.D.; et al. Maintenance of ATP Homeostasis Triggers Metabolic Shifts in Gas-Fermenting Acetogens. Cell Syst. 2017, 4, 505-515. [CrossRef]

41. Hurst, K.M.; Lewis, R.S. Carbon monoxide partial pressure effects on the metabolic process of syngas fermentation. Biochem. Eng. J. 2010, 48, 159-165. [CrossRef]

42. Phillips, J.R.; Clausen, E.C.; Gaddy, J.L. Synthesis gas as substrate for the biological production of fuels and chemicals. Appl. Biochem. Biotechnol. 1994, 45, 145-157. [CrossRef]

43. Jack, J.; Lo, J.; Maness, P.-C.; Ren, Z.J. Directing Clostridium ljungdahlii fermentation products via hydrogen to carbon monoxide ratio in syngas. Biomass Bioenergy 2019, 124, 95-101. [CrossRef]

44. Bengelsdorf, F.R.; Poehlein, A.; Linder, S.; Erz, C.; Hummel, T.; Hoffmeister, S.; Daniel, R.; Dürre, P. Industrial Acetogenic Biocatalysts: A Comparative Metabolic and Genomic Analysis. Front. Microbiol. 2016, 7, 1036. [CrossRef] [PubMed]

45. Richter, H.; Molitor, B.; Wei, H.; Chen, W.; Aristilde, L.; Angenent, L.T. Ethanol production in syngas-fermenting Clostridium ljungdahlii is controlled by thermodynamics rather than by enzyme expression. Energy Environ. Sci. 2016, 9, 2392-2399. [CrossRef]

(C) 2020 by the authors. Licensee MDPI, Basel, Switzerland. This article is an open access article distributed under the terms and conditions of the Creative Commons Attribution (CC BY) license (http://creativecommons.org/licenses/by/4.0/). 